\section{Sandra Šustić}

sansustic@gmail.com

Izvorni znanstveni rad/

Original scientific paper Primljen/Received: 27. 4. 2018.

UDK

7.072 Fisković, C. 7.025.3/.4(497.5-3 Dalmacija)“19“ $\mathrm{DOI}$ http://dx.doi.org/10.17018/portal.2018.8

\section{Cvito Fisković i glavne značajke} restauriranja umjetnina u Konzervatorskom zavodu za Dalmaciju

SAŽETAK: Zahvaljujući djelatnosti Cvite Fiskovića (Orebić, 24. prosinca 1908. - Split, 13. srpnja 1996.), jednog od najuvaženijih hrvatskih povjesničara umjetnosti i konzervatora, mnogim je dalmatinskim umjetninama u drugoj polovici 20. stoljeća sačuvana cjelovitost, osigurano restauriranje i povijesnoumjetnička analiza. Ta tematika, iako je često o njoj pisala stručna javnost, do sada nije bila sustavno uobličena i prezentirana, poglavito $u$ kontekstu uspostave i razvoja prve restauratorske radionice $u$ Dalmaciji. Analitičkom obradom arhivske građe rasvijetljene su okolnosti njezina osnivanja, napredak $u$ radu te glavne odrednice djelovanja. Posebno se proučavaju interdisciplinarne metode rada $u$ otkrivanju i restauriranju umjetničkih djela, poglavito dalmatinskih umjetnika. Rezultati istraživanja nedvojbeno su pokazali da je Cvito Fisković imao veoma važnu ulogu u formiranju i unapređivanju službe za zaštitu pokretnih spomenika u Hrvatskoj, pri čemu je modernizirao domete svojih preteča i proširio povijesnoumjetničke studije tretiranih umjetnina.

KLJUČNE RIJEČI: Cvito Fisković, Konzervatorski zavod za Dalmaciju, restauratorska radionica u Splitu, restauriranje umjetnina, pokretni spomenici, „domaći“ majstori, interdisciplinarna suradnja
$\mathrm{P}$ očetkom druge polovice 20. stoljeća nepregledni broj povijesnih slika i skulptura na hrvatskoj obali bio je zapušten i nezaštićen. Štoviše, razaranja tijekom Drugog svjetskog rata prouzročila su dodatna oštećenja, krađe i gubitke mnogih znamenitih umjetnina na obali. ${ }^{1}$

Takvo alarmantno stanje zahtijevalo je ubrzano organiziranje službe zaštite, koja će se fokusirati ponajprije na umjetnine iz Dalmacije. Međutim, sustavni obilazak terena, uvid u muzeje, riznice i zbirke provodio se tek u poraću. Spašavanje iznimno velikog broja dalmatinskih pokretnih spomenika nije moglo ući u zadaću postojećih institucija povezanih s problematikom zaštite. Dok je Restauratorski zavod, osnovan pri Jugoslavenskoj akademiji znanosti i umjetnosti u Zagrebu (dalje JAZU), ${ }^{2}$ prije svega radio na restauriranju oštećenih predmeta Akademijinih galerija i muzeja, Savezni institut za zaštitu spomenika u Beogradu ${ }^{3}$ odabirao je umjetnine prema kriteriju tzv. „saveznog“ značaja ugroženih predmeta. Stoga je priliku za opstanak dalmatinske baštine omogućio dolazak novog ravnatelja Konzervatorskog zavoda za Dalmaciju ${ }^{4} 1945$. godine - povjesničara umjetnosti i konzervatora Cvite Fiskovića (sl. 1). ${ }^{5}$

Odmah nakon rata Cvito Fisković je sa skupinom hrvatskih povjesničara umjetnosti i arheologa sudjelovao $u$ komisijama za ratnu štetu u porušenom Zadru, ${ }^{6}$ a prvu 


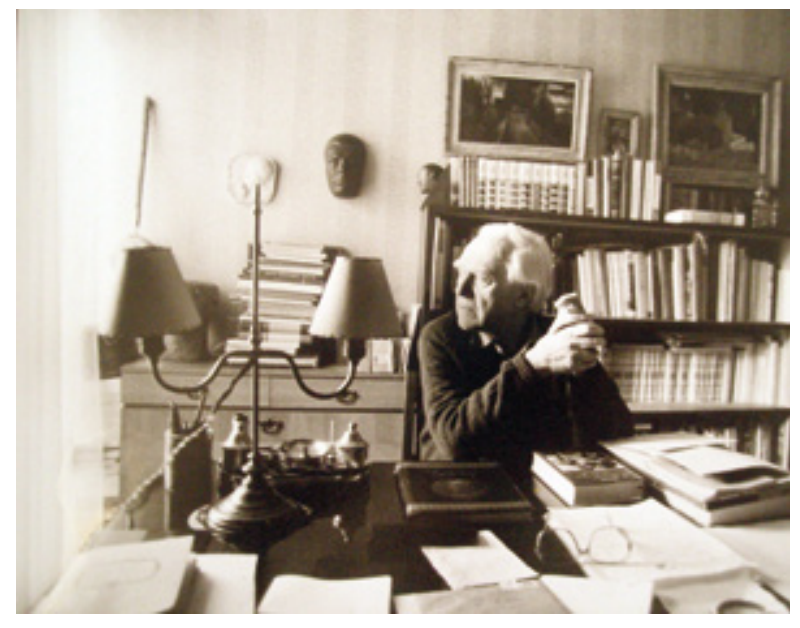

1. Cvito Fisković u radnom ambijentu (Arhiv Konzervatorskog odjela, dalje AKO, album Cvite Fiskovića, bez oznake) Cvito Fiskovic at work (Ministry of Culture of the Republic of Croatia, Conservation Department Archives, Cvito Fisković album, no tag)

inventuru uništenih i otuđenih spomenika tiskao je $\mathrm{u}$ radu Spomenici i okupator 1946. godine, utemeljivši prvi časopis za povijest umjetnosti u Hrvatskoj Prilozi povijesti umjetnosti $u$ Dalmaciji. ${ }^{7} \mathrm{U}$ tim ranim godinama $\mathrm{u}$ Konzervatorskom su zavodu djelovali povjesničari umjetnosti Ksenija Cicarelli, Nevenka Bezić-Božanić i Davor Domančić te arhitekti Momčilo Berber i Jerko Marasović. ${ }^{8}$ Upravo je navedena služba zaštite utvrdila stanje pokretnih spomenika na terenu. Tada su nastale i prve registracije pokretnih spomenika, a važno je istaknuti da je Cvito Fisković osim splitskog pokrivao i dubrovačko područje. ${ }^{9}$

Osnutkom prve restauratorske radionice na području Dalmacije, koja je od 1954. godine djelovala pod okriljem Konzervatorskog zavoda u Splitu, Cvito Fisković počeo je rad na sustavnom restauriranju povijesnog slikarstva i skulpture. Upravo je restauratorski rad za njega bio od naročite važnosti za uspješnu djelatnost Zavoda jer je, kako navodi, to bio ,jedini djelotvoran i najvidljiviji od svih ostalih poslova koje Zavod obavlja zaštićujući spomenike kulture“. ${ }^{10}$ Kao povjesničar umjetnosti, u restauratorskom je radu uočio priliku da se umjetninama osim restauriranja omogući i povijesnoumjetnička analiza te valorizacija. Treba napomenuti da je Fisković bio znanstvenik širokog obrazovanja i kulture, a njegova analiza i valorizacija umjetničkog djela nije se temeljila samo na formalno-stilskoj analizi, nego jednakovrijedno na arhivskom radu i poznavanju srednjovjekovnog latiniteta i mletačkog talijanskog jezika i govora. Takvim je radom iznio na vidjelo brojne zapise i ugovore te imena slikara, kipara i majstora umjetničkog obrta koji su djelovali u Dalmaciji i u Italiji, koje je nazvao „domaćim“ majstorima.

Dakako, doprinos Cvite Fiskovića zaštiti povijesnog slikarstva i skulpture često je opisivana tema u stručnoj javnosti, no gotovo u pravilu unutar općenitih njegovih zasluga na polju zaštite spomenika. ${ }^{11}$ Stoga će se u ovom članku - koji je dio šireg istraživačkog rada - prvi put, na temelju arhivskih izvora, rasvijetliti taj nedovoljno istraženi segment njegove djelatnosti. ${ }^{12} \mathrm{U}$ fokusu istraživanja su razvitak i metodologija djelovanja prve restauratorske radionice u Dalmaciji s ciljem sustavnog uobličavanja prikupljene arhivske građe o neposrednom doprinosu Cvite Fiskovića u zaštiti pokretnih spomenika. Posebno se proučavaju interdisciplinarne metode rada koje je primijenio u otkrivanju i restauriranju umjetničkih djela, poglavito dalmatinskih umjetnika.

\section{Osnutak prve restauratorske radionice u Dalmaciji 1954. godine}

Iako se kao službeni datum osnutka restauratorske radionice u Splitu najčešće navodi siječanj 1954. godine, ${ }^{13} u$ arhivu Konzervatorskog zavoda za Dalmaciju nije pronađena uredba o njezinu utemeljenju. Štoviše, arhivski spisi upućuju na to da se radilo o dugotrajnom procesu formiranja u kojem je ključnu ulogu imao Cvito Fisković. Naime, duboko svjestan značenja restauratorske radionice u Dalmaciji, kao član JAZU-a ${ }^{14}$ poticao je i lobirao za njezino osnivanje unutar Konzervatorskog zavoda u Splitu. ${ }^{15}$ Njegova je nastojanja napokon prepoznao i uvažio Odjel za likovne umjetnosti i muziku pri JAZU-u u Zagrebu, na sjednici 7. svibnja 1952. godine. Spomenuti Odjel donio je odluku da se Savjetu za prosvjetu, nauku i kulturu Narodne Republike Hrvatske (dalje NRH) predloži osnivanje restauratorskih zavoda u sklopu Konzervatorskog zavoda Hrvatske u Zagrebu, kao i u sklopu Konzervatorskog zavoda za Dalmaciju u Splitu. Odluka je obrazložena „velikim brojem objekata“ na području sjeverne Hrvatske te na području Dalmacije, kod kojih se pokazala potreba za hitnim restauratorskim zahvatima. Budući da tako opsežan rad nisu mogli provoditi isključivo djelatnici Restauratorskog zavoda JAZU-a, te zbog potrebe da se na vrijeme osposobe mladi stručnjaci, odluka je prihvaćena 21. svibnja 1952. godine, i to na sjednici Predsjedništva JAZU-a (sl. 2). ${ }^{16}$

Potkraj lipnja 1952. godine u Konzervatorski zavod za Dalmaciju stigao je dopis Savjeta za prosvjetu, nauku i kulturu NRH s prijepisom prijedloga JAZU-a o osnivanju restauratorskih zavoda pri konzervatorskim zavodima. U dopisu se zahtijevalo da Cvito Fisković dostavi mišljenje o toj tematici te da navede trenutačne mogućnosti za uspostavljanje radionice. Osim toga, trebao je izvijestiti o mogućnosti odabira stručnog kadra te procijeniti financijska sredstva potrebna za njihovo uređenje. ${ }^{17} \mathrm{U}$ odgovoru dostavljenom odmah, početkom srpnja, ustvrdio je: „Za sada zamišljamo, budući da nedostaje stručnjaka, da nam se dodijeli jedan slikar ili restaurator početnik, koji se je već počeo baviti restauriranjem i pokazao za to volju i smisao. Takvog stručnjaka trebalo bi potražiti u Zagrebu 


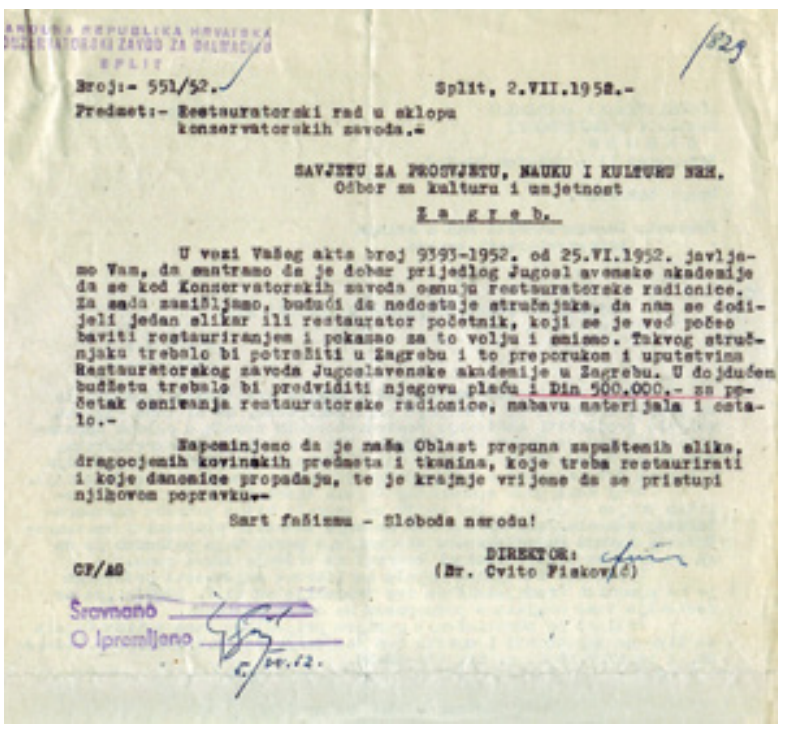

2. Dopis Cvite Fiskovića od 2. srpnja 1952. godine o restauratorskom radu u sklopu Konzervatorskih zavoda (AKO, fol. 1951, 501 - 1000, snimila S. Šustić)

Memo by Cvito Fisković dated $2^{\text {nd }}$ July 1952 on restoration within the Conservation Departments (Ministry of Culture of the Republic of Croatia, Conservation Department Archives, fol. 1951 501-1000, S. Šustić)

i to preporukom i uputstvima Restauratorskog zavoda Jugoslavenske akademije u Zagrebu. “18 Prijeku potrebu za osnivanjem radionice posebno je istaknuo opisom stanja na terenu, kojemu je posvjedočio tijekom evidentiranja spomenika: „Napominjemo da je naša Oblast prepuna zapuštenih slika, dragocjenih kovinskih predmeta i tkanina, koje treba restaurirati i koje danomice propadaju, te je krajnje vrijeme da se pristupi njihovom popravku.“19 Slijedom toga, potkraj rujna pristiglo je odobrenje Savjeta za prosvjetu, nauku i kulturu da Konzervatorski zavod za Dalmaciju u prijedlogu proračuna za 1953. godinu predvidi sredstva za „uspostavljanje i uzdržavanje restauratorske radionice“, kao i nužno povećanje osoblja. ${ }^{20}$

Međutim, zanimljivo je upozoriti i na novonastala pitanja i dvojbe o kojima se raspravljalo u travnju 1953. godine na Sastanku konzervatora u Splitu, koji je organizirao Savezni institut za zaštitu spomenika u Beogradu. Na sastanku je sudjelovao i Cvito Fisković, a njegovo pismo tajniku Odjela Krsti Hegedušiću, u kojem zahvaljuje što ga je počastio time da bude predstavnik njihova Odjela, otkriva nekoliko važnih podataka o temama sastanka, tadašnjim aktualnostima i stavovima koje je (Fisković) zauzeo i žustro branio: „U diskusiji, a nakon razgovora $\mathrm{s}$ restauratorom Lončarićem zastupao sam stajalište odjela u pitanju konzerviranja i restauriranja umjetnina. Pored toga usprotivio sam se prijedlogu da se ukinu restauratorske radionice pri akademijama i ostalim ustanovama $\mathrm{i}$ istaknuo usluge, koje nam je učinila restauratorska radionica JAZU popravljajući nekoliko starih umjetničkih slika u Zadru, u Šibeniku, u Korčuli i u Dubrovniku, te u ostalim mjestima našeg primorja.“ ${ }^{21}$

Dakako, jedan od presudnih čimbenika glede vremena osnutka restauratorske radionice bio je pronalazak stručnog kadra koji će, uz potrebne kvalifikacije, obavljati redovite restauratorske djelatnosti na pokretnim spomenicima. Podobnog kandidata Fisković je pronašao u ljeto 1953. godine. Bio je to Filip Dobrošević koji je netom maturirao na smjeru kiparstva u Školi za primijenjenu umjetnost u Splitu. ${ }^{22}$ Arhivski spisi otkrivaju da je radno mjesto preparatora ${ }^{23}$ Konzervatorskog zavoda otvoreno već u srpnju 1953. godine, no sve do kraja te godine nije bilo izgleda da se radionica oformi. ${ }^{24}$ Naime, spriječen služenjem vojnog roka, Dobrošević je na mjesto preparatora $^{25}$ postavljen tek 26. studenoga 1953., ${ }^{26}$ a radni odnos s punim radnim vremenom počeo je od siječnja 1954. godine $^{27}$ pa se taj datum uzima kao službeni datum osnutka restauratorske radionice.

Brojni arhivski dopisi u kojima se evidentiraju njegove specijalizacije koje su potom uslijedile svjedoče o dugogodišnjoj ustrajnosti Cvite Fiskovića da mu omogući usavršavanje u struci. ${ }^{28}$ No važno je istaknuti da je Fisković i nakon Dobroševićeva osposobljavanja održavao kontinuirane veze s JAZU-om, Saveznim institutom za zaštitu kulturnih spomenika u Beogradu te Zavodom za zaštitu spomenika Makedonije. Ta je suradnja bila vrlo raznovrsna; uz to što su te institucije splitskoj restauratorskoj radionici omogućavale stručna savjetovanja o tehnologiji restauriranja, ${ }^{29}$ pomagale su joj i u opskrbi teško dostupnog restauratorskog materijala. ${ }^{30}$ No ono što je bilo svakako najvažnije jest to što su i dalje slale svoje stručnjake na terenske zahvate $u$ Dalmaciju i što su preuzimale i transportirale visokokvalitetne umjetnine s područja djelovanja Konzervatorskog zavoda za Dalmaciju u svoje laboratorije. ${ }^{31}$

\section{Afirmacija dalmatinskih majstora: prioritetni projekt Konzervatorskog zavoda za Dalmaciju}

Primarne interese $u$ pogledu zaštite spomenika Cvito Fisković najavio je već 1937. godine, kad je na Filozofskom fakultetu u Zagrebu obranio doktorsku disertaciju o korčulanskoj katedrali, s tezom o pretežitom stvaralaštvu dalmatinskih umjetnika na hrvatskoj obali. ${ }^{32}$ Tada je detaljnim arhivskim istraživanjem otkrio niz dalmatinskih graditelja i kamenoklesara koji su na području Korčule djelovali od početka 15. do 18. stoljeća. Nacionalni značaj umjetnina dalmatinskih majstora zaokupljao ga je i početkom četrdesetih godina, kad je, u službi ravnatelja Prosvjetnog odjela Oblasnog narodnooslobodilačkog odbora Dalmacije (dalje ONOOD), prilikom terenskih obilazaka, uvidio golemu količinu neistraženih i teško pristupačnih umjetnina različitih povijesno-umjetničkih 


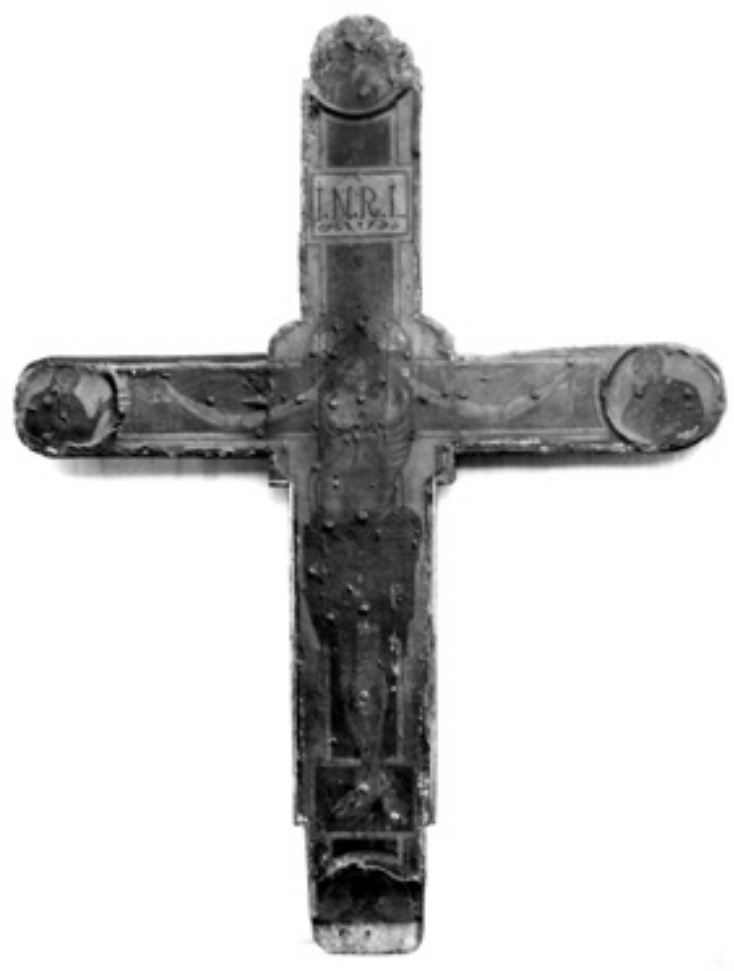

3. Naslikano raspelo iz samostana klarisa - zatečeno stanje 1958. godine (AKO-ST-ARR, mapa s fotografijama, bez oznake) Painted crucifix from the convent of Poor Clares, condition in 1958 (Ministry of Culture of the Republic of Croatia, Conservation Department Archives, Archives of the conservation workshop, album of photographs, no tag)

razdoblja. ${ }^{33}$ Posvjedočio je nepovoljnim uvjetima njihova smještaja u malim muzejima, crkvenim riznicama te gradskim i privatnim zbirkama, što je dakako ubrzavalo već odavno započet proces degradacije krhkih materijala. U tim je umjetninama, kako sam piše, vidio „vjekove naše prošlosti“, a njihovu spašavanju posvetio je cijeli radni vijek.

Obnovom rada Konzervatorskog zavoda za Dalmaciju 1945. godine omogućio je postupnu realizaciju svojega nauma, najavljenog u dopisu Ministarstvu prosvjete 23. lipnja iste godine - netom prije osnutka Zavoda: „Taj folklor je u našoj Oblasti bogat i raznolik, a mi mu baš na ovoj obali koju je tuđin uvijek priključivao tuđoj kulturnoj sferi moramo dati osobito značenje, jer baš to narodno blago, nošnja, melodije i igre potvrđuju slavensku kulturu naše Oblasti. “34 Prije njegova aktivnog angažmana, djelatnost - kako ih je često nazivao - „domaćih umjetnika“ na Jadranu nije bila dovoljno poznata, pa prema tome nije bilo uočeno ni njihovo značenje $u$ kulturnoj afirmaciji dalmatinske umjetnosti na Jadranu. ${ }^{35}$ Osnovni uspjesi $u$ rješavanju te specifične povijesnoumjetničke problematike, od 1945. godine nadalje, sastojali su se upravo u obrađivanju umjetničkog stvaranja

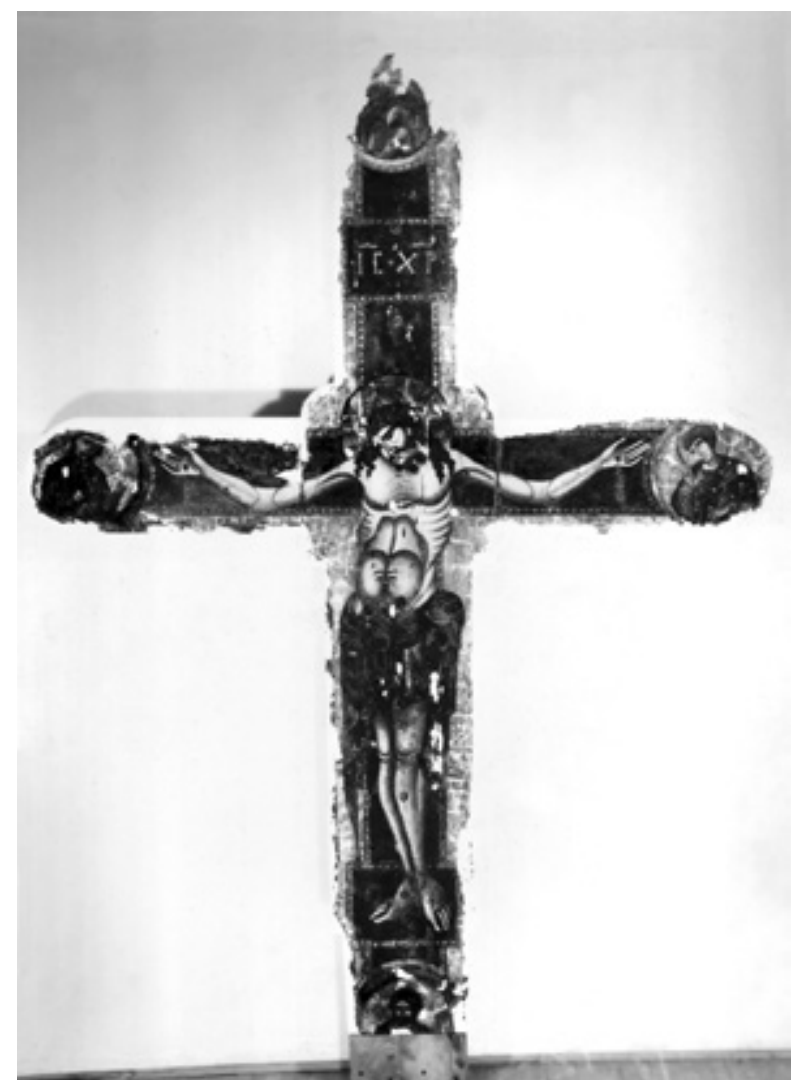

4. Raspelo tijekom zahvata 1959. godine (AKO-ST-ARR, mapa s fotografijama, bez oznake)

Crucifix during the 1959 conservation (Ministry of Culture of the Republic of Croatia, Conservation Department Archives, Archives of the conservation workshop, album of photographs, no tag)

dalmatinskih graditelja, kipara, slikara, rezbara i zlatara na jadranskoj obali. Rad na realizaciji toga projekta odrazio se na cijelu djelatnost Konzervatorskog zavoda pa su prilikom zaštite, registracije i restauriranja kulturno-umjetničke baštine provođene temeljite studije o umjetninama. To je ponajprije podrazumijevalo obavezno znanstveno istraživanje $u$ arhivima te komparativna istraživanja epohe, stila, smjera i autorstva kojima pojedini spomenik pripada. Važno je istaknuti da ta istraživanja ne iznose samo način i metode konzerviranja, nego postavljaju spomenike u kulturno-povijesne okvire i analiziraju njihove karakteristike. Stoga se može ustvrditi da je afirmacija dalmatinskih majstora na povijesnoumjetničkoj sceni postala jednim od glavnih projekata institucije. O tome svjedoči i službeni dopis od 5. prosinca 1955. o restauriranju umjetnina u Dalmaciji koji je upućen Jugoslavenskoj akademiji znanosti i umjetnosti u Zagrebu. Tom je prigodom Cvito Fisković pozdravio namjeru JAZU-a da i dalje restaurira „trošne i oštećene umjetnine u Dalmaciji”, no napomenuo je da bi Zavod želio dati prednost oštećenim djelima starih hrvatskih slikara 15. i 16. stoljeća. ${ }^{36}$ Predložio je da se najprije restauriraju poliptisi, pale i slike na dubrovačkom području, 


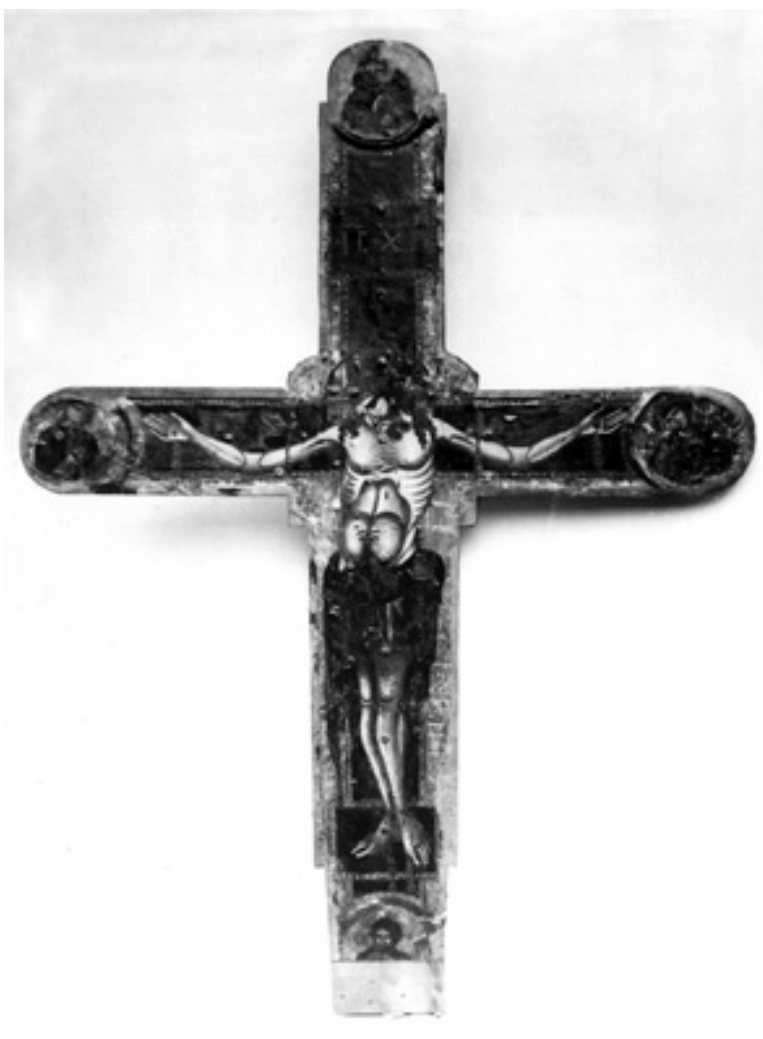

5. Raspelo poslije zahvata 1959. godine (AKO-ST-ARR, mapa s fotografijama, bez oznake) Crucifix after the 1959 conservation (Ministry of Culture of the Republic of Croatia, Conservation Department Archives, Archives of the conservation workshop, album of photographs, no tag)

istaknuvši da osim umjetničkog te umjetnine imaju i nacionalno značenje.

Upravo je zato zanimljiv i njegov odgovor na Upitnik ICOM-a od 26. prosinca 1955. godine, poslan Saveznom institutu za zaštitu spomenika u Beogradu, u kojem kao osnovni istraživački projekt Zavoda za 1956. i 1957. godinu navodi „restauraciju slika lokalne dalmatinske škole od 15. do 16 stoljeća“. ${ }^{37}$ No spašavanje tih djela potaknula je i jedna tehnološka karakteristika koja se tiče nositelja slika. Naime, u dopisu koji je uputio Župnom uredu u Milni na Braču u srpnju 1961. upozorio je na opasnost koja je prijetila starim slikama naslikanim na dasci: „Naš plan rada usredotočen je na popravak starijih slika od 13 . - 15. stoljeća, koja su u vrlo teškom stanju, jer su slikane na drvu, koje je izjela crvotočina. Stoga nam je dužnost da te umjetnine spasimo od propasti, a to iziskuje mnogo rada $i$ vremena. “38

Budući da je Cvito Fisković na razini institucije postavio zadaću da se prioritetno konzerviraju i restauriraju umjetnine dalmatinskih majstora, Zavod je sljedećih godina radio poglavito na proučavanju tih djela. Kapitalni primjeri afirmacije dalmatinskih umjetnika bili su otkriće tzv. splitske slikarske škole ${ }^{39}$ i obogaćivanje slikarskog opusa Blaža Jurjeva Trogiranina. ${ }^{40}$ Istraživanja koja su iz toga proizišla rezultirala su brojnim znanstvenim radovima uz pomoć kojih je afirmirano i znanstveno dokazano stvaranje dalmatinskih umjetnika na primorju od 9. do 20. stoljeća. Rezultate svojega rada djelatnici Zavoda najčešće su objavljivali u časopisu Zavoda Prilozi povijesti umjetnosti u Dalmaciji koji je Cvito Fisković uređivao od 1946. godine. Tu su se od početka objavljivali recenzirani znanstveni članci s područja povijesti umjetnosti i arheologije. U skladu s djelokrugom i programskim zadacima Konzervatorskog zavoda za Dalmaciju, profil časopisa zasnivao se na tekstovima u kojima su se predstavljala istraživanja umjetničke baštine Dalmacije, od slikarstva, kiparstva, arhitekture, urbanizma do arheologije i primijenjenih umjetnosti. U vrijeme djelovanja Cvite Fiskovića u Prilozima se - povijesnoumjetničkim analizama i arhivskim istraživanjima - snažno isticala uloga upravo „domaćih“ majstora od 9. do 19. stoljeća. ${ }^{41}$ Naime, osnovnu je zadaću časopisa predočio $u$ dopisu Regionalnog zavoda za zaštitu spomenika u kolovozu 1975. godine: „U Prilozima smo osobito isticali ulogu domaćih majstora da isključivo naučnim dokazima i arhivskim dokumentima suzbijemo stranu propagandu koja je osobito prije rata tvrdila da je naša kulturno umjetnička baština djelo stranih umjetnika.“42 Uz to, studije o dalmatinskim umjetnicima objavljivane su i u ostalim stručnim i književnim časopisima u Beogradu, Zagrebu, Ljubljani i Splitu, a iznosili su ih i na međunarodnim kongresima za povijest umjetnosti, zatim $u$ izdanjima Jugoslavenske akademije u Zagrebu i Dubrovniku te $u$ izdanjima Srpske akademije. ${ }^{43}$

Međutim, pedesetih godina prošloga stoljeća potraga za dalmatinskim majstorima nastavljala se i u inozemstvu. To se prije svega odnosilo na istraživanje arhiva i umjetničkih djela u susjednoj Italiji, gdje su se dalmatinski umjetnici također isticali od 14. do 18. stoljeća. ${ }^{44}$ Službeni prijedlog znanstvenog projekta Rad primorskih umjetnika XIV-XVIII stoljeća i izvoz njihovih djela u Italiju Cvito Fisković uputio je Savjetu za naučni rad NRH u Zagrebu u svibnju 1961. godine. ${ }^{45}$ Zavod je tada prikupio mnogo arhivske građe o „domaćim“ majstorima, no trebalo je sustavno ispitati mjesta uzduž talijanske obale na Jadranu te provesti fotodokumentaciju zatečenih umjetnina i spomenika. Ispunjenje te zadaće bio je još jedan znatan doprinos afirmaciji dalmatinske umjetnosti na Jadranu, čime je iznova potvrđena njezina bogata zastupljenost, pa tako i potražnja u Italiji.

\section{Važnost timskog rada: interdisciplinarna suradnja restauratora i povjesničara umjetnosti}

Rasprave o teorijskim problemima restauriranja nakon Drugoga svjetskog rata postale su sve prisutnije, a pitanja do kojeg stupnja vratiti prvotni izgled umjetnine i na 


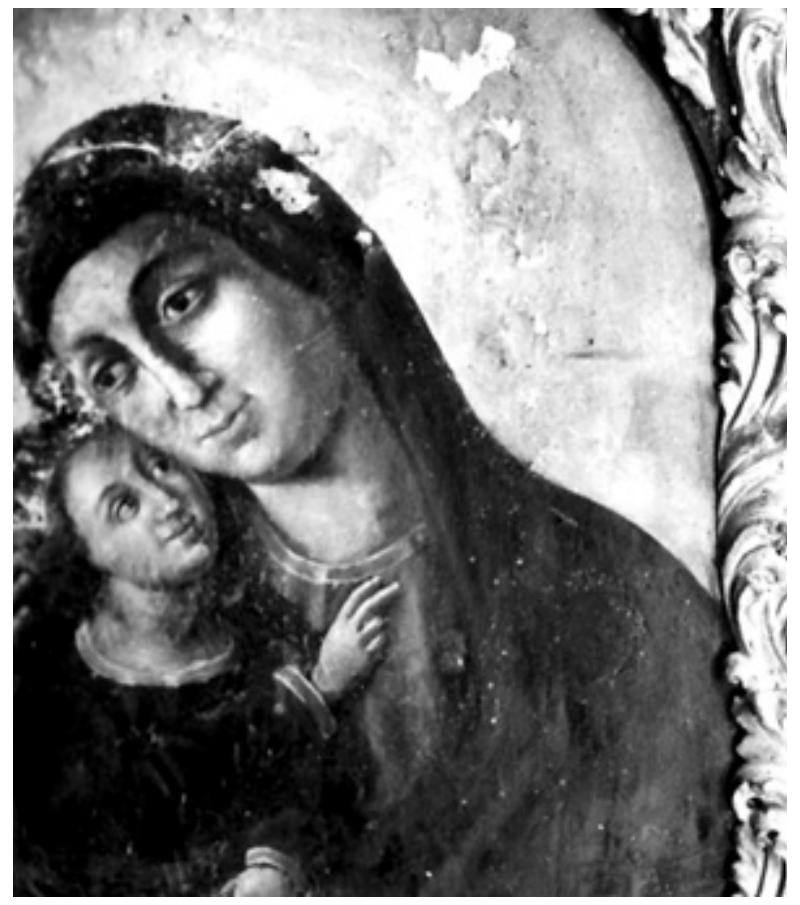

6. Bogorodica s Djetetom iz crkve sv. Stjepana na Sustipanu prije zahvata (AKO-ST-ARR, mapa s fotografijama, bez oznake) Madonna and Child from the Church of St. Stephen on Sustipan, before conservation (Ministry of Culture of the Republic of Croatia, Conservation Department Archives, Archives of the Conservation Workshop, album of photographs, no tag)

koji način valorizirati povijesne i estetske vrijednosti umjetničkog djela dobila su međunarodni karakter. ${ }^{46} \mathrm{Te}$ su teme okupirale i Cvitu Fiskovića, pa je u dopisu iz 1958. godine, poslanom redakciji Vjesnika u Zagrebu, istaknuo: „Pri poslu konzerviranja treba uvijek uskladiti naučno proučavanje i ispitivanje objekta na kojem se vrši konzervatorski zahvat i način njegove zaštite i valoriziranja njegovog značenja.“47 Rješenje je vidio $u$ organizaciji koja se temelji na zajedničkom radu povjesničara umjetnosti i restauratora komplementarnih znanja i vještina, koji imaju zajednički cilj i entuzijazam $u$ analiziranju umjetničkih djela te uzajamnu odgovornost u konačnom restauriranju. ${ }^{48}$ Upravo su zato važna njegova razmišljanja o restauriranim umjetninama, poput onih objavljenih $u$ članku Riječ pri otvaranju izložbe restauriranih umjetnina u Splitu, objavljenom u časopisu Mogućnosti 1968. godine: „Popravljena i očišćena umjetnina je spašena od daljnjeg propadanja; ona više nije zabačena, već registrirana, a često i objavljena; preko nje je izložene, osvježene i osigurane pristup javnosti k majstorovu izrazu neposredniji; stručnjaci pak u njoj mogu jasnije uočiti odlike njegove ruke, znak njegove škole i vremena.“49

Međutim, važno je istaknuti da se prednost te suradnje očitovala već od prvog koraka zaštite, tj. evidencijom spomenika na terenu. Upravo su zahvaljujući umijeću povjesničara umjetnosti uočene i selektirane umjetnine visoke

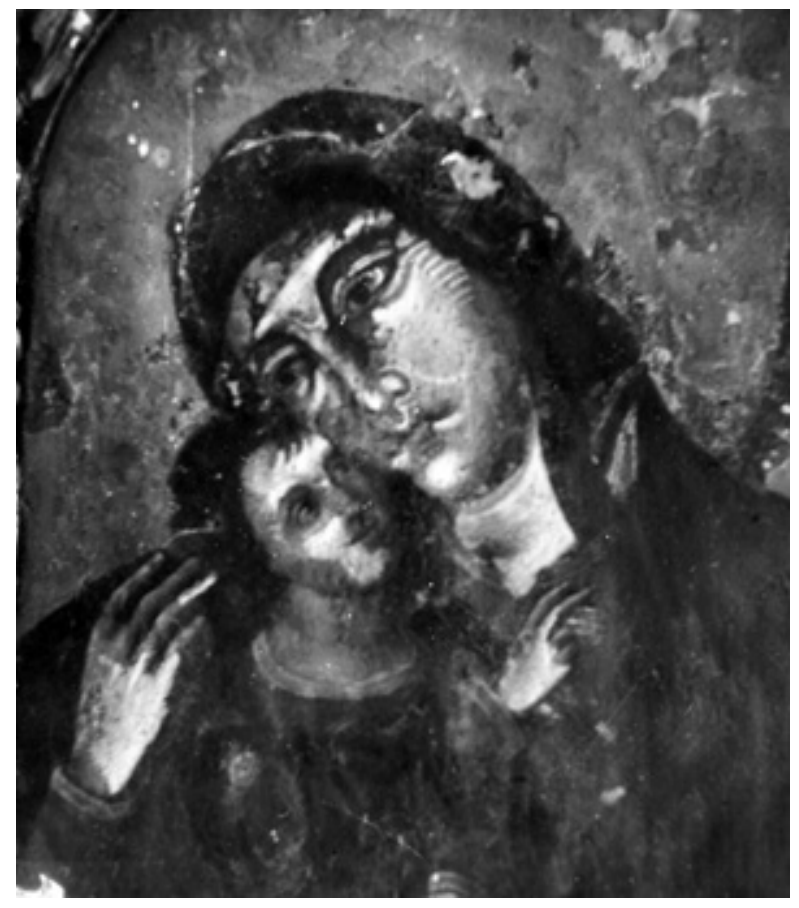

7. Slika tijekom zahvata (AKO-ST-ARR, mapa s fotografijama, bez oznake)

Painting during conservation (Ministry of Culture of the Republic of Croatia, Conservation Department Archives, Archives of the Conservation Workshop, album of photographs, no tag)

povijesno-umjetničke važnosti. Jednom kad je oštećena umjetnina pristigla $u$ radionicu, događao se niz pripremnih radnji koje su prethodile konzervatorsko-restauratorskom zahvatu, o čemu svjedoči tekst preuzet iz ispitne radnje restauratora Špire Katića koju je pripremio za polaganje stručnog ispita 1966. godine: „Praksa naše ustanove jest da umjetnine prilikom preuzimanja na popravak upišemo $u$ registar popravljenih umjetnina. Zatim se otvori dosje specijalno za tu umjetninu te se unose njene generalije: naziv, autor, škola, vlasnik, vrsta materijala iz koje je umjetnina izrađena i inventarski broj. Komisija za pregled umjetnina, u kojoj su zastupljeni historičari umjetnosti, restauratori i drugi stručnjaci vezani za umjetnost i umjetnička ostvarenja, sastaje se i daje svoje stručno mišljenje za konzerviranje i restauriranje djela. Da bi dosje bio potpun vrši se fotografiranje prije početka radova, za vrijeme radova (a ukoliko naiđemo na neke nepredviđene novine slika se sve u detaljima) zatim nakon konzerviranja i restauriranja umjetnine. Restaurator bilježi sve svoje radove koje vrši od početka do svršetka posla i unosi karakteristike izvršenih poslova. ${ }^{\text {"50 }}$

Naime, dok je metodologija rada Restauratorskog zavodu JAZU-a u većoj mjeri bila fokusirana na restauratorska istraživanja i njihovo publiciranje, u splitskoj restauratorskoj radionici nadzor povjesničara umjetnosti i konzerviranje-restauriranje bili su čvrsto povezani. ${ }^{51}$ 
Sačuvani primjerci dokumentacija iz arhiva restauratorske radionice svjedoče o brojnim takvim suradnjama stručnjaka s različitih područja. Od 1956. godine, u slučaju važnijih umjetnina i/ili specifične problematike, formiraju se tročlana ili četveročlana povjerenstva sastavljena u pravilu od jednog restauratora i nekoliko povjesničara umjetnosti. ${ }^{52}$ Štoviše, zabilježeni su slučajevi u kojima se uz imena djelatnika Konzervatorskog zavoda za Dalmaciju kao članova povjerenstva, spominju i imena vanjskih suradnika - eminentnih stručnjaka na određenom području povijesti umjetnosti i restauriranja. To je bio slučaj s restauriranjem glasovitog slikanog raspela iz 12. stoljeća $u$ vlasništvu franjevačkog samostana u Zadru, koje je preuzeto 1969. godine. Zbog velike važnosti umjetnine oformljeno je čak peteročlano povjerenstvo u kojem su osim Cvite Fiskovića, Davora Domančića i Filipa Dobroševića odlučivali i Grgo Gamulin te Ivo Petricioli. ${ }^{53}$ Iako se Ivica Lončarić, djelatnik Restauratorskog zavoda JAZU-a, ne nalazi na spomenutom popisu, dopis Cvite Fiskovića napisan 14. svibnja 1969. svjedoči o tome da je i on sudjelovao u savjetovanju procesa restauriranja, i to upravo na Fiskovićev poziv. ${ }^{54}$ Očito je da su vanjski suradnici birani u skladu s njihovim afinitetima i specijalnostima u struci. Valja spomenuti još jedan primjer ciljane selekcije vanjskih suradnika, a to je slučaj restauriranja slike Uznesenje Mateja Ponzonija Pončuna iz 17. stoljeća iz crkve Gospe Stomorice u Gornjem selu na Šolti. Ondje je uz Davora Domančića Cvito Fisković postavio najboljeg poznavatelja baroka u Dalmaciji, Krunu Prijatelja, da nadzire tijek i opseg restauratorskih radova. ${ }^{55}$

Sasvim razumljivo, zadaci timskog rada bili su ispitivanje trenutačnog stanja umjetničkog djela, iznalaženje najpogodnije radne strategije za umjetninu i nadziranje samog procesa restauriranja. Ta je suradnja rezultirala brojnim pozitivnim posljedicama. Naime, stajališta povjesničara umjetnosti u mnogim su slučajevima pomogla restauratorima $u$ potrazi za primjerenijom metodom konzerviranja-restauriranja, koja će $u$ što većoj mjeri poštovati namjeru umjetnika. S druge strane, restauratorska istraživanja upućivala su na specifične tehničke pojedinosti na umjetničkim djelima, koje bi u protivnom ostale nezamijećene. Indikativna je tvrdnja Cvite Fiskovića koju je iznio u elaboratu o radu Konzervatorskog zavoda za Dalmaciju iz studenoga 1968. godine: „Tek nakon restauriranja, koje su njeni namještenici (restauratorske radionice) u strogoj suradnji sa povjesničarima umjetnosti koji rade u Zavodu izveli na pojedinoj umjetnini, mogao se otkriti i uočiti visoki kvalitet i opredijeliti školu ili majstora dotične umjetnine koja je dotle bila slabo vidljiva, trošna i pocrnjela. ${ }^{56}$ Shvaćao je da su restauratori u neposrednom doticaju s umjetninama stekli sposobnost razumijevanja slikarskih materijala te upoznali strukturu umjetničkih djela i tehnologiju izrade. Stoga su njihova opažanja o izvornim slojevima i naknadnim intervencijama na umjetninama utjecala na njegove studije, kao i na studije ostalih povjesničara umjetnosti koji su proučavali restaurirane umjetnine. Opseg otkrivenih autora $i$ datacija obuhvatio je razdoblje od 12. do 19. stoljeća, te majstore poput Blaža Jurjeva, Dujma Vuškovića, Lovre Dobričevića, Tripa Kokolje, Nicole Grassija, Girolama da Santa Crocea, Mateja Pončuna i kipara Jurja Petrovića. ${ }^{57}$

Posebno valja istaknuti saznanja o slikama na drvu do 15. stoljeća, budući da je jedna od najvažnijih interdisciplinarnih studija bila upravo ona posvećena dalmatinskoj romaničkoj likovnoj baštini na dasci. ${ }^{58}$ Taj je projekt počeo restauriranjem slike Bogorodica s Djetetom iz crkve Gospe od Zvonika u Splitu, koje su izveli zagrebački restauratori Restauratorskog zavoda JAZU-a 1957. godine. ${ }^{59}$ Iako je Cvito Fisković u početku držao da je riječ o trečentističkoj umjetnini, analogijom s drugim slikama na dasci, koje je splitska radionica restaurirala šezdesetih godina 20. stoljeća, uočio je njezinu poveznicu s romaničkim slikarstvom. ${ }^{60}$ Nakon čišćenja izdašnog sloja prljavštine na velikom naslikanom raspelu iz samostana klarisa (sl. 3, 4 i 5) i uklanjanja baroknog preslika s ikone Bogorodice s Djetetom u crkvi sv. Stjepana na Sustipanu (sl. 6 i 7), usporedio je ta dva djela sa spomenutom slikom iz crkve Gospe od Zvonika u Splitu i našao im mnoga zajednička obilježja u stilu i tehnici slikanja. Stoga je, povezujući te tri slike, 1960. godine prvi put iznio pretpostavku da je u Splitu u drugoj polovici 13. i prvih godina 14. stoljeća postojala posebna radionica ili škola romaničkog slikara koji je pod utjecajem duečentističkog toskanskog slikarstva slikao sa svojim pomoćnicima i učenicima. ${ }^{61} \mathrm{Tu}$ je tezu potkrijepio pronalaskom i četvrte romaničke slike vrlo sličnih obilježja koja također prikazuje Bogorodicu s Djetetom, a pronađena je u crkvici Gospe od Žnjana, $u$ istočnom dijelu splitskog polja. Naime, nakon što su povjesničari umjetnosti naslutili postojanje starijeg izvornog slikanog sloja pod kasnijim preslikom, restauratori su otkrili vrijednu romaničku umjetninu koja je već i činjenicom što je bila preslikana poslužila kao pouzdan dokaz za postojanje slikarske radionice $u$ Splitu. ${ }^{62}$ Međutim, prilikom restauriranja navedene slike pod gornjim romaničkim slojem uočeno je postojanje još ranije slike iste tematike, no ponešto drugačije kompozicije, što je unijelo novo svjetlo $u$ rasprave o mogućnosti postojanja slikarske radionice $u$ Splitu. Slijedom toga, Cvito Fisković uputio je poziv na suradnju Tomislavu Markoviću, ravnatelju Centralnog ureda za kriminološka ispitivanja Zagreb, s ciljem da uz pomoć neinvazivne dijagnostičke tehnike snimanja dopre do donjih slojeva boje. ${ }^{63}$ Unatoč neuspjelim rezultatima snimanja, interdisciplinarnom suradnjom dokazano je postojanje jedne vrlo stare likovne kulture u Splitu, poznate i sa zidnog slikarstva na koju se nastavljala lokalna radionica slika na drvu. 


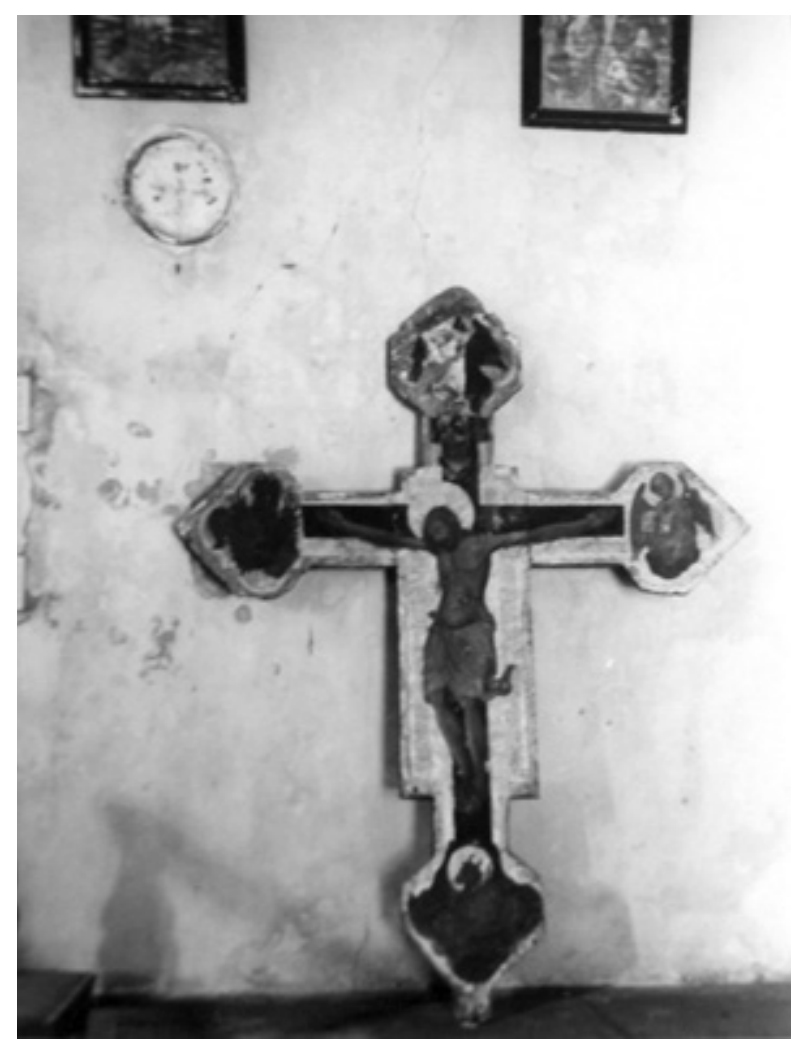

8. Raspelo Blaža Jurjeva Trogiranina iz crkve sv. Nikole u Stonu snimljeno u rujnu 1957. godine (fototeka AKO-ST, inv. br. 49 11, broj negativa: L 4642)

Crucifix by Blaž, son of Juraj of Trogir, from the Church of St. Nicholas in Ston, photographed in 1957 (Photographs of the Conservation Department for Dalmatia, inv. no. 49 11, negative number L 4642, dated September 1957)

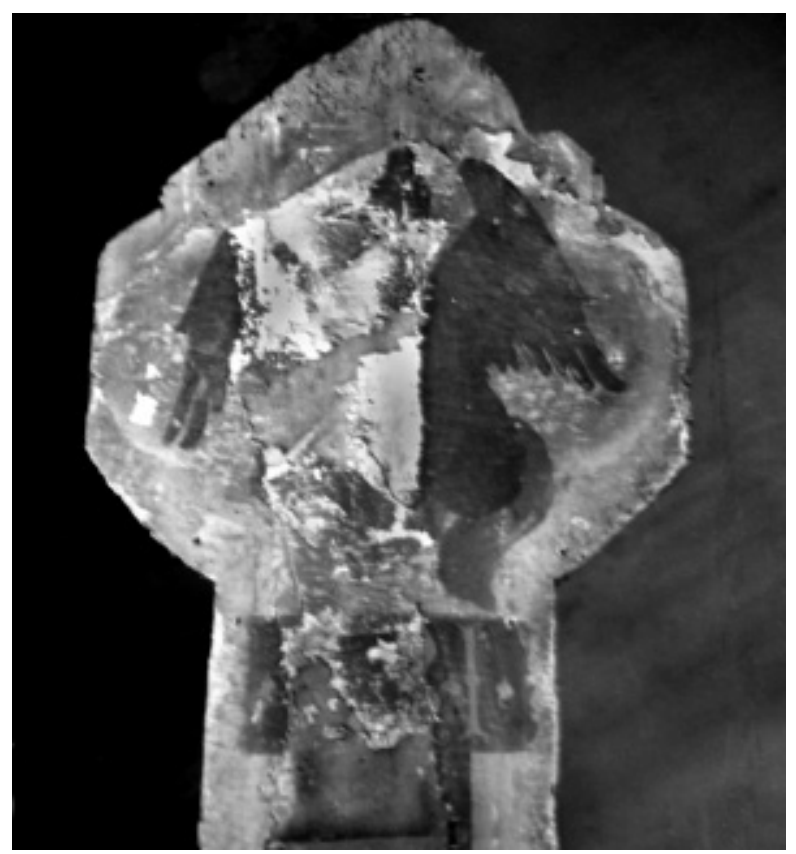

10. Detalj raspela snimljen u ožujku 1959. godine prije zahvata (AKO-ST, inv. br. 9546, broj negativa: R 3112)

Detail of the crucifix from 1959, before conservation (Photographs of the Conservation Department for Dalmatia, inv. no. 9546, negative number R 3112, dated March 1959)

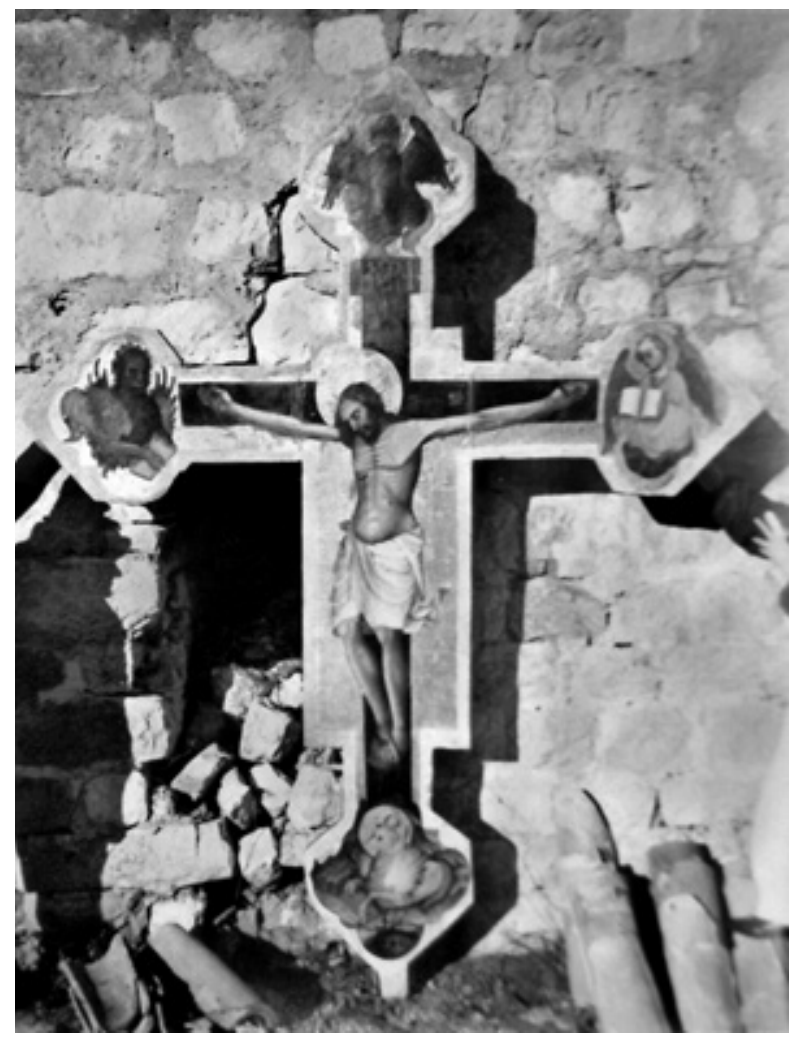

9. Raspelo snimljeno 1962. godine (fototeka AKO-ST, inv. br. 14036, broj negativa: $F 38$, snimio D.D. 9. prosinca 1962.) Crucifix photographed in 1962 (Photographs of the Conservation Department for Dalmatia, inv. no. 14036, negative number F 38, D. D. $9^{\text {th }}$ December 1962)

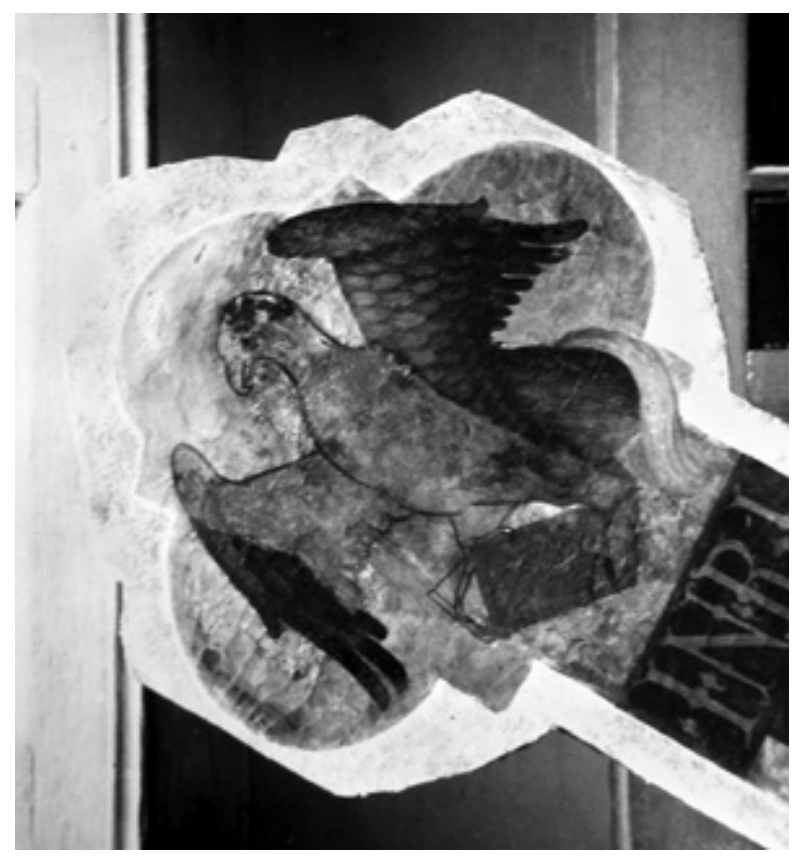

11. Raspelo, detalj nakon zahvata (fototeka AKO-ST, inv. br. 9033 broj negativa: R 2740, snimljeno u prosincu 1959.)

Detail of the crucifix after conservation (Photographs of the Conservation Department for Dalmatia, inv. no. 9033, negative number $R$ 2740, dated December 1959) 
Otkrićem splitske romaničke slikarske škole ${ }^{64}$ Cvito Fisković je opovrgnuo dotadašnje atribucije i datacije povjesničara umjetnosti, koji su ranije proučavali spomenute umjetnine i pisali o njima. ${ }^{65}$ No te su slike prijašnjim istraživačima bile gotovo potpuno skrivene pod naslagama prljavštine, požutjelog laka i naknadnih preslika. Stoga se može ustvrditi da je upravo zahvaljujući interdisciplinarnim studijama, koje je proveo u bliskoj suradnji s restauratorima, Cvito Fisković imao jedinstvenu priliku zaviriti ispod površine tih umjetnina i odrediti njihovu autentičnost, koja je nakon toga priznata među znanstvenicima u zemlji i inozemstvu. ${ }^{66}$

Nadalje, interdisciplinarna suradnja povjesničara umjetnosti i restauratora utjecala je i na preispitivanje opusa pojedinih umjetnika. U tom smislu valja upozoriti na dopis Cvite Fiskovića iz travnja 1972. godine u kojem obrazlaže dobrobiti te suradnje: „Povjesničari umjetnosti koji u zemlji i u inozemstvu obrađuju povijest slikarstva i pojedine umjetnine, proučavaju tražeći im vrijeme postanka i autore, koristili su se mnogo restauriranim umjetninama $u$ ovoj radionici, pronašli im vrijeme postanka i opredijelili im školu. Prema tome radionica je popravkom umjetnina doprinijela upoznavanju djela i otkrivanju novih slika poznatih umjetnika Nikole Božidarevića, Blaža Jurjeva, Ivana Ugrinovića, Paola Venecijana, Dujma Vuškovića, Mihajla Hamzića, Lovra Dobričevića, Jacopa Tintoretta, Palme Starijeg, Nikole Grassija, Matije Pončuna i ostalih slikara, sve do Celestina Medovića i Vlaha Bukovca i ostalih. “67

Evidentno je da je djelatnost splitske restauratorske radionice bila bitna karika u povezivanju i određenju mnogih umjetnika, no među navedenim slikarima paradigmatičan je Blaž Jurjev Trogiranin. ${ }^{68}$ Svakako valja istaknuti raspelo iz crkve sv. Nikole u Stonu (sl. 8 - 11) koje je Fisković još 1956 . godine pribrojio tom majstoru, ${ }^{69}$ no nakon što je djelo restaurirano 1961. godine, svoje je opažanje potkrijepio neoborivim argumentima. ${ }^{70}$ Nadalje, tek kad su u Restauratorskoj radionici Konzervatorskog zavoda za Dalmaciju u Splitu 1963. godine uklonjeni preslici na raspelu iz crkve sv. Frane u Splitu (sl. 12 - 16), uočio je autorstvo Blaža Jurjeva Trogiranina ${ }^{71}$ pa je $u$ dopisu Grgi Gamulinu konstatirao: „Danas sam konačno vidio očǐšćeno raspelo iz franjevačke crkve $u$ našoj restauratorskoj radionici i smatram da je to rad Blaža Jurjeva Trogiranina, koji djeluje sasma drugačije nego kad je bio premazan. Izvršio sam usporedbe sa stonskim i pisao odmah dr. Strgačiću da mi ispiše dokument u cjelini, koji sam najavio već 1950 . u Marulićevom Zborniku, a iz kojeg se vidi da je Blaž doista radio za splitske franjevce na obali. ${ }^{422}$

Osim Cvite Fiskovića, restauratorski rad pratili su i drugi povjesničari umjetnosti, također djelatnici Konzervatorskog zavoda za Dalmaciju. Naime, završavajući stručnu evidenciju kulturno-umjetničkih spomenika Kaštela, Ksenija Cicarelli pronašla je u Kaštel Štafiliću kod obitelji Mladice ud. Ćipiko još jedno djelo majstora 15. stoljeća - Bogorodicu $s$ Djetetom medu anđelima slikanu temperom na drvu. Tek nakon što je u restauratorskoj radionici uklonjen debeo sloj potamnjelog laka i prljavštine, provedena je analogija s Gospom u ružičnjaku i s Bogorodicom na srednjem polju poliptiha iz trogirske katedrale te je slika pripisana Blažu Jurjevu Trogiraninu. ${ }^{73}$

Tim saznanjima priključena su i dva vrsna Jurjeva remek-djela: poliptih u korčulanskoj opatskoj zbirci te poliptih u kapeli sv. Jerolima trogirske katedrale. Ta je djela Cvito Fisković istaknuo među njegovim radovima temeljem analogije stila, a zatim je arhivskim dokumentima, ugovorima i obračunima potkrijepio vlastitu atribuciju i potvrdio da je Juraj doista njihov autor. Nadalje, na restauriranje korčulanskog poliptiha iz crkve Svih svetih osvrnuo se akademik Igor Fisković u članku „Druga izložba starih umjetnina popravljenih u Splitu" objavljenom u časopisu Mogućnosti 1969. godine. Naime, tek je nakon restauriranja odbijena pretpostavka o povećanom doprinosu Blaževih suradnika u izradi toga poliptiha, pa je istaknuo da su rezultati zalaganja restauratora pridonijeli promicanju znanstvenih gledišta o poliptihu. Spomenuo je i ulogu restauratora $u$ slučaju atribucije raspela $u$ crkvi sv. Franje: „Ali je upravo njihovom zaslugom, a u običajenoj suradnji s povjesnicima umjetnosti, u liku Krista islikanom na drvenom križu u crkvi splitskih konventualaca, prepoznata ista ruka. ${ }^{.74}$

Međutim, iako je za trogirski poliptih Blaževo autorstvo već potkrijepio arhivskim dokumentom, Cvito Fisković je uvidio da se slikama ne može izreći konačni sud prije restauratorskog istraživanja i zahvata čišćenja. Stoga je 1973. godine, uz mnoga umjetnička djela, omogućio restauratorski postupak i tom poliptihu. Nakon zahvata, očišćeni poliptih pomogao je $u$ daljnjem proučavanju njegova stila i tehnike slikanja. Osim toga, restauratorski zahvat otkrio je još jednu bitnu informaciju o nastanku poliptiha. Restauratori su pronašli na gornjem dijelu drvenih ploča sa svecima zapis ispisan glagoljicom u crvenoj boji brzim potezom kista. Odmah potom Cvito Fisković je u projekt uključio vanjske suradnike: povjesničarku Benediktu Zelić-Bučan, stručnjakinju za glagoljicu te prof. Vjekoslava Štefanića. ${ }^{75}$ Suradnici su potvrdili autentičnost natpisa i povezali ga sa slikarom, zaključivši da je poliptih naslikan na Bijaćima pokraj Trogira. ${ }^{76}$

Naposljetku, uspjeh interdisciplinarne suradnje povjesničara umjetnosti i restauratora potvrdile su tri važne izložbe restauriranih umjetnina u prostoru Matice hrvatske u Splitu, od kojih je prva priređena 1967., ${ }^{77}$ druga 1968. godine prigodom međunarodnog kongresa, odnosno kolokvija povjesničara umjetnosti u Splitu, ${ }^{78}$ a treća 1969. godine. ${ }^{79}$ Izložbe su obuhvatile djela "domaće“ umjetnosti, nastajala od 13. do 18. stoljeća. Bila je to jedinstvena prilika da se uoče sličnosti među pojedinim umjetninama i riješe neke nejasnoće glede autorstva te da se prikazanim 


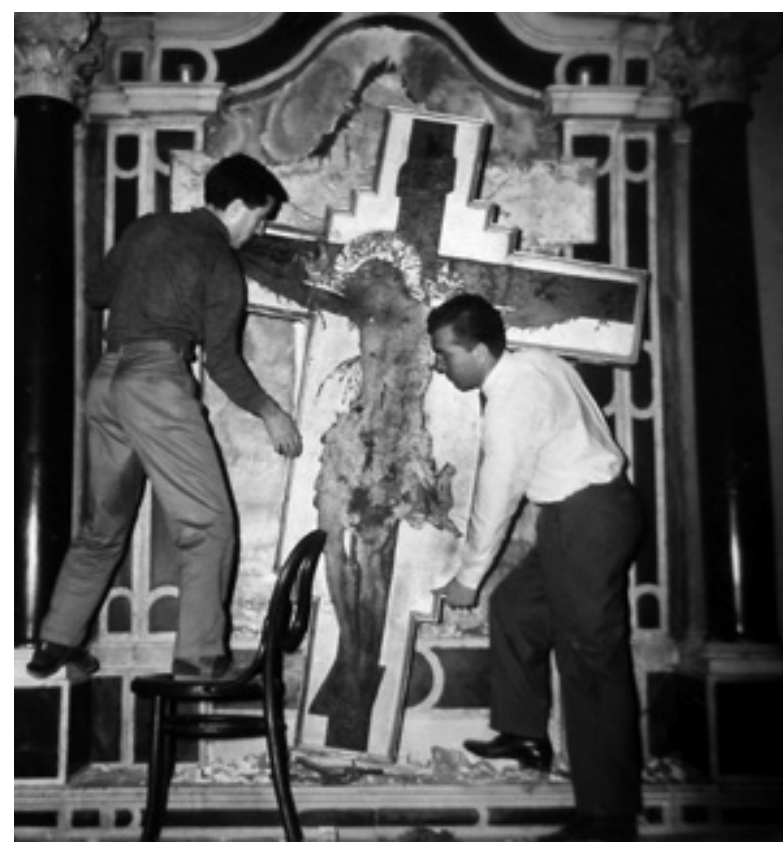

12. Demontiranje raspela Blaža Jurjeva Trogiranina u crkvi sv. Franje u Splitu (fototeka AKO-ST, inv. br. 13697, broj negativa: R 6350, snimio I. M. 20. svibnja 1963.)

Disassembly of the crucifix by Blaž, son of Juraj of Trogir, in the Church of St. Francis in Split (Photographs of the Conservation Department for Dalmatia, inv. no. 13697, negative number R 6350, I. M. $20^{\text {th }}$ May 1963)

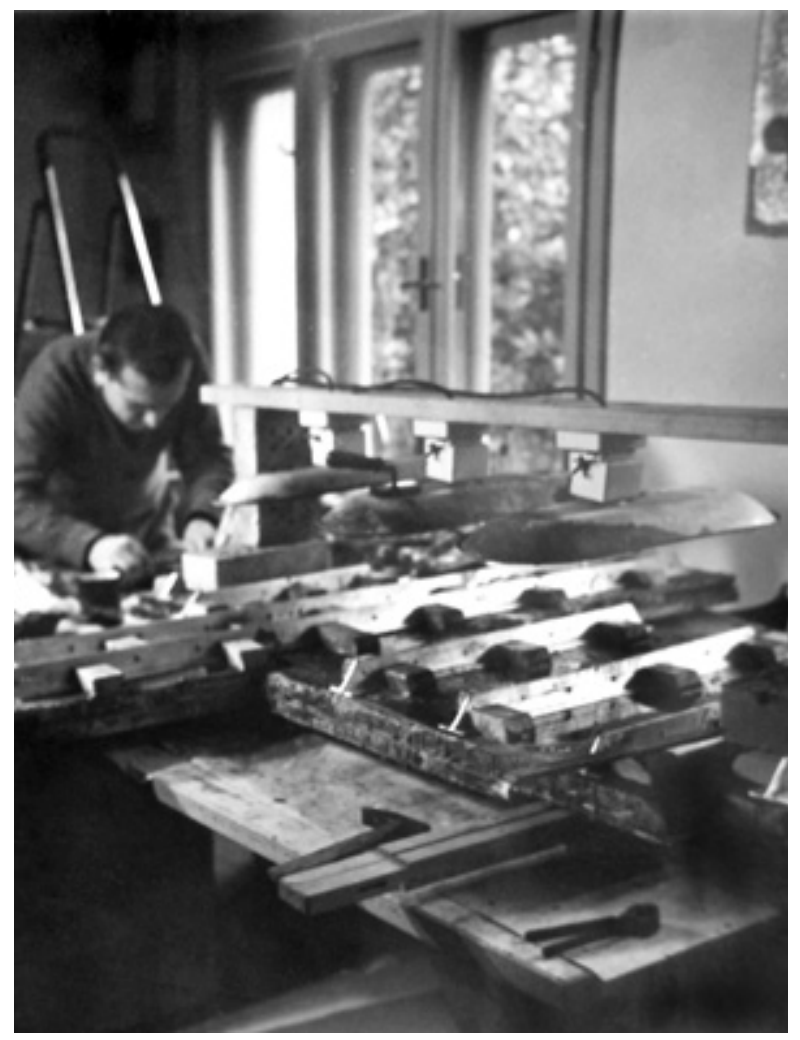

14. Raspelo tijekom impregniranja drva. Izvor: fototeka AKO-ST, inv. br. 15221, broj negativa: R 7668 (snimio D. D. 18. veljače 1964.) Crucifix during wood impregnation (Photographs of the Conservation Department for Dalmatia, inv. no. 15221, negative number $R 7668$, D. D. $18^{\text {th }}$ February 1964)

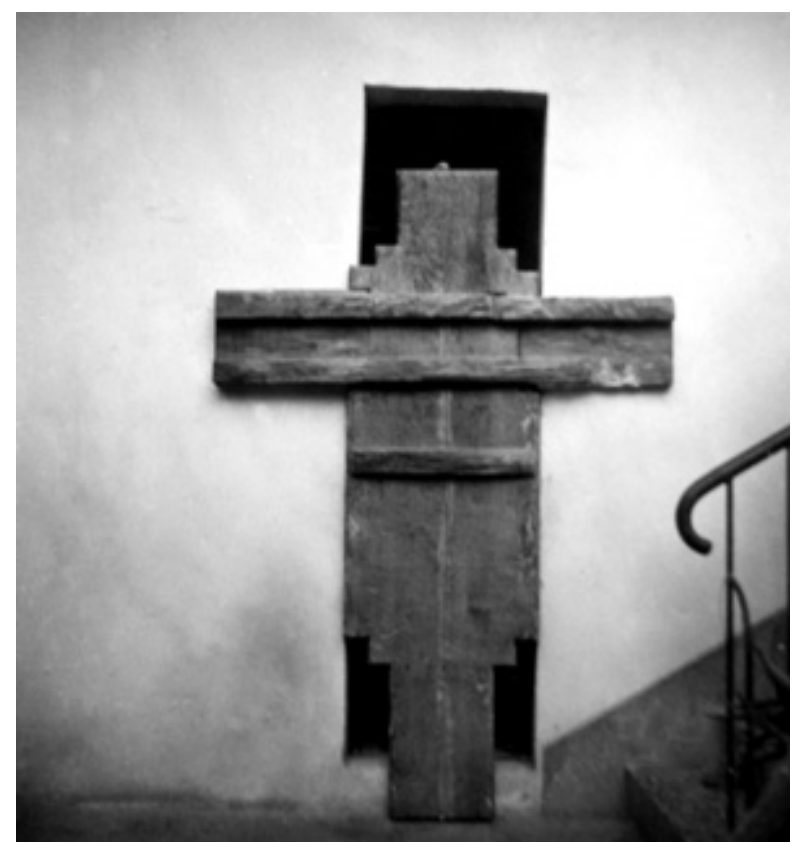

13. Raspelo snimljeno s poleđine (fototeka AKO-ST, inv. br. 13700 , broj negativa: R 6352-3, snimio I. M. 20. svibnja 1963.) Back of the crucifix (Photographs of the Conservation Department for Dalmatia, inv. no. 13700, negative number R 6352-3, I. M. $20^{\text {th }}$ May 1963)

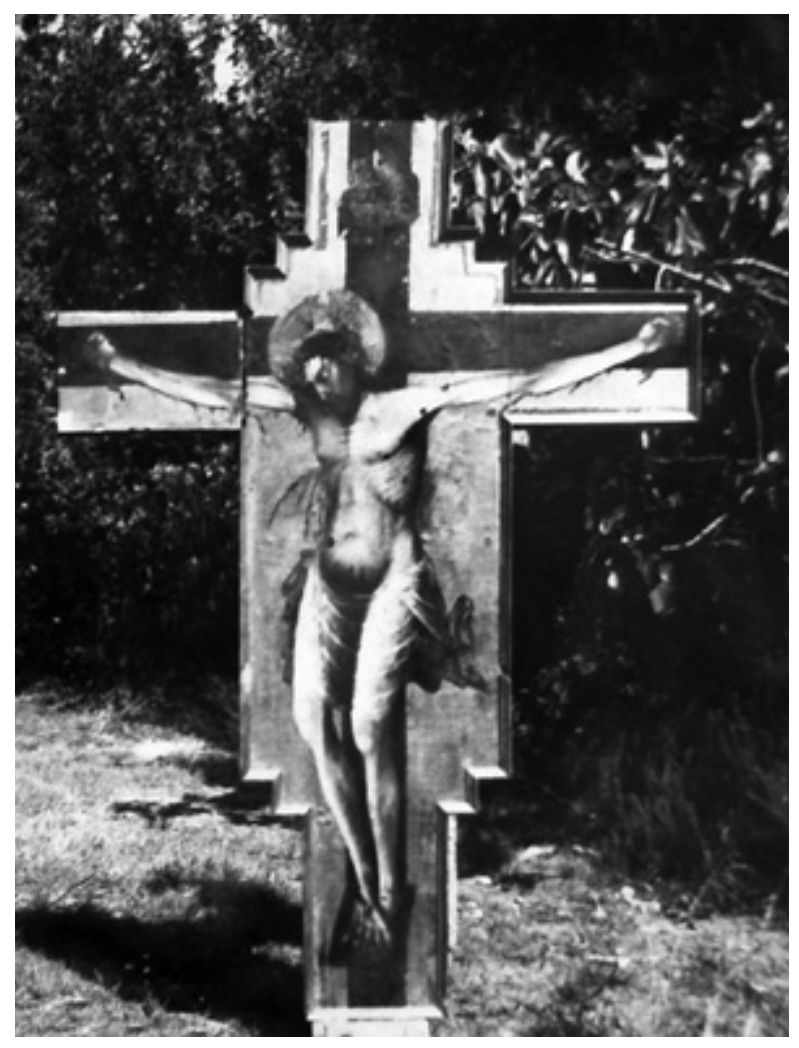

15. Raspelo tijekom čišćenja (fototeka AKO-ST, inv. br. 14713, broj negativa: R 7 (?) $26-8$, snimio I. M. svibanj 1963.)

Crucifix during cleaning (Photographs of the Conservation Department for Dalmatia, inv. no. 14713, negative number $R 7$ (?) $26-8$, I. M. May 1963) 
fotografijama zatečenih stanja umjetnina upozori na složen postupak restauratorskih zahvata. Izložbe su stoga imale dvojaki karakter; ponajprije je hrvatskoj javnosti omogućen uvid u presjek radioničke prakse, u kojima su se ogledali različiti pristupi u restauriranju, dok je s druge strane okupljanje umjetnina potaknulo energične povijesnoumjetničke rasprave o temeljnim pitanjima uloge domaćih škola najstarijeg dalmatinskog slikarstva na drvu. Kritika stranih i domaćih stručnjaka o tim izložbama bila je pohvalna, što potvrđuje i nagrada Grada Splita uručena restauratorskoj radionici $u$ listopadu 1968 . godine za istaknuti rad i postignute rezultate $u$ umjetnosti, kulturi i znanosti. ${ }^{80}$ Budući da su najpotpunije spoznaje o djelu Blaža Jurjeva Trogiranina također nastale zahvaljujući djelatnosti splitske restauratorske radionice, ${ }^{81} 1986$. godine priređena mu je monografska izložba u Muzeju hrvatskih arheoloških spomenika. Time su omogućene daljnje usporedbe i utvrđene dotadašnje spoznaje o doprinosu njegova slikarstva gotičkog sloga 15. stoljeća u Dalmaciji.

\section{Zaključak}

Ovaj je rad na osnovi sustavnog bibliografskog i arhivskog istraživanja nastojao prikazati ključne teorijske i praktične aspekte djelatnosti Cvite Fiskovića u zaštiti, otkrivanju i restauriranju dalmatinskih pokretnih spomenika. Izvještajima i dokumentima poslovanja Konzervatorskog zavoda za Dalmaciju rasvijetljene su okolnosti osnivanja splitske restauratorske radionice. Naime, kao član JAZU-a, Fisković je poticao osnivanje te radionice unutar Konzervatorskog zavoda u Splitu i za to lobirao, a arhivski podaci upućuju na to da je njegova nastojanja napokon prepoznao i uvažio Odjel za likovne umjetnosti i muziku pri JAZU-u u Zagrebu 1952. godine. Osim toga, obrazložen je dug proces formiranja radionice koji je, između ostalog, ovisio o pronalasku i dostupnosti podobnog kandidata - restauratora. Specifičnost radne strategije očituje se u oblikovanju programâ kojima je primarni cilj bio afirmacija dalmatinskih majstora. Rezultati toga rada pokazali su da umjetnička baština na obali nije samo „import iz tuđine“, naprotiv, da ima individualni pečat i veliko nacionalno značenje.

Iako se djelatnost Cvite Fiskovića u zaštiti i restauriranju povijesnog slikarstva i skulpture na obali treba analizirati uzimajući u obzir kontekst vremena u kojem je djelovao, njegova se ideja o suradnji restauratora i povjesničara umjetnosti pokazala kao suvremen i vrlo primjenjiv alat $\mathrm{u}$ zaštiti povijesnog slikarstva i skulpture. Naime, uvažavanjem uloge restauratora koji su poznavali materijalnost umjetnina, prikupljene su različite informacije koje su znatno pridonijele povijesti umjetnosti. Uključivanje stručnjaka različite naobrazbe osnažilo je projekte splitske restauratorske radionice i omogućilo autoritativnije zaključke na polju povijesti umjetnosti. Istraživanje je nedvojbeno

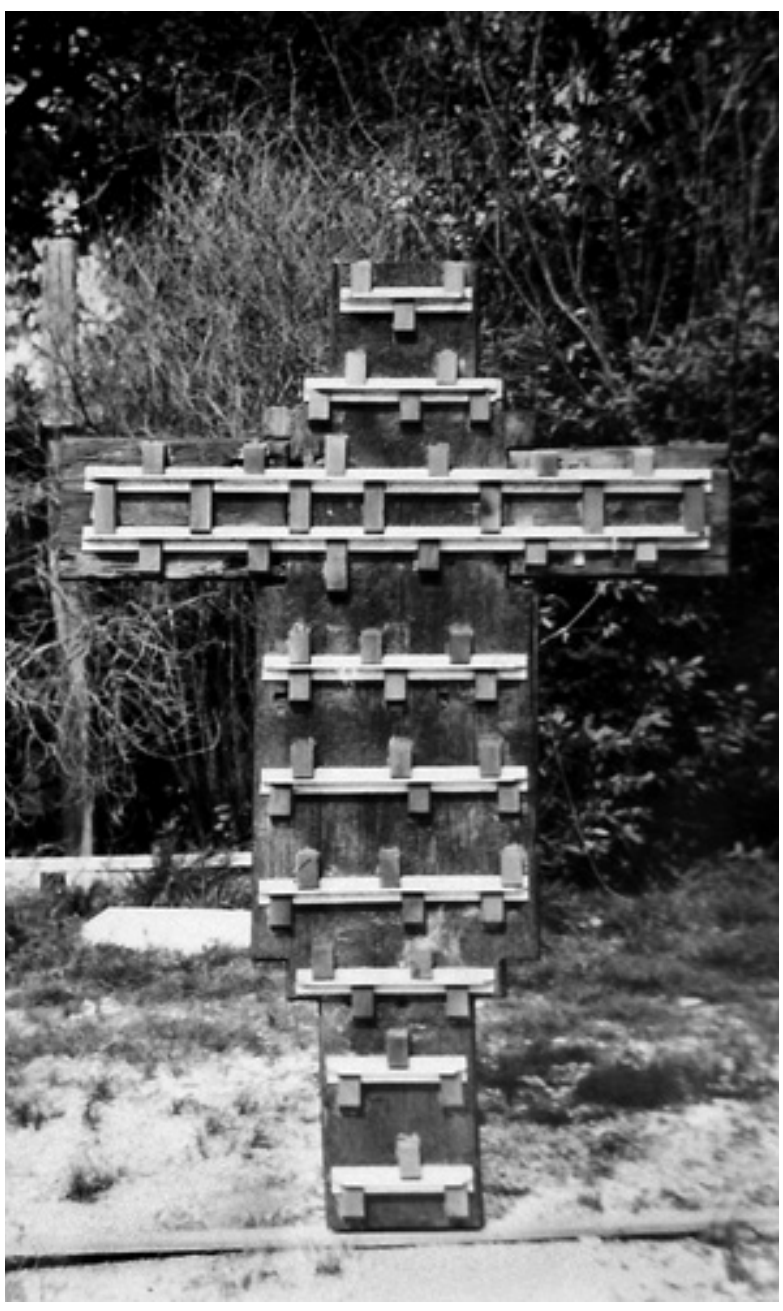

16. Raspelo snimljeno s poleđine nakon zahvata (fototeka AKO-ST, inv. br. 15477, broj negativa: G 459, snimio D. D. 3. travnja 1964.) Back of the crucifix, after conservation (Photographs of the Conservation Department for Dalmatia, inv. no. 15477, negative number G 459, D. D. $3^{\text {rd }}$ April 1964)

pokazalo da je Cvito Fisković imao veoma važnu ulogu u formiranju i unapređivanju službe za zaštitu pokretnih umjetnina u Hrvatskoj; modernizirao je domete svojih prethodnika i proširio povijesnoumjetničke studije tretiranih umjetnina.

\section{Zahvale}

Na dragocjenom vodstvu, vrijednim savjetima i pomoći u razvijanju strukture istraživanja autorica zahvaljuje: prof. dr. sc. Ivi Babiću, prof. dr. sc. Josipu Belamariću, prof. dr. sc. Igoru Fiskoviću, dr. sc. Zoraidi Demori Staničić i prof. dr. sc. Marku Špikiću. Zahvaljuje i dr. sc. Vanji Kovačić na prezentiranju arhivske građe Konzervatorskog odjela u Splitu, kao i na odobrenju za proučavanje te građe, pročelnici Službe za odjele izvan Zagreba Ivani Svedružić Šeparović na uvidu u popise restauriranih umjetnina te voditelju Restauratorskog odjela Split Branku Pavazzi na brojnim konzultacijama o djelatnosti restauratorske radionice. 


\section{Bilješke}

1 Prema službenim podacima, u Jugoslaviji je poslije rata okradeno oko 10.000 crkava, samostana, muzeja i zbirki. JOSIP BELAMARIĆ, 1988., 11-31.

2 Restauratorski zavod u Zagrebu razvio se iz prve restauratorske radionice u Hrvatskoj, osnovane 1942. godine pri Muzeju za umjetnost i obrt. Najprije radionicom, a onda i samim Zavodom rukovodio je uvaženi restaurator Zvonimir Wyroubal. Godine 1945. pridružuje mu se vrsna restauratorica Stanislava Dekleva, a potom Leonarda Čermak i Ivica Lončarić 1948. godine. SAGITA MIRJAM SUNARA, 2011.; SAGITA MIRJAM SUNARA, 2017.

3 Savezni institut, osnovan 1950. godine, uspostavio je vrlo rano veze s Kraljevskim institutom za zaštitu umjetničkog naslijeđa u Bruxellesu. Njegovi su djelatnici (kemičari i slikari-restauratori) odlazili u Belgiju radi uspoređivanja tehničkih metoda koje se primjenjuju u jednoj i drugoj zemlji. PAUL COREMANS, 1960., 5-9. 4 Na temelju Općeg zakona o zaštiti spomenika kulture i prirodnih rijetkosti od 4. listopada 1946., Vlada NRH je 23. lipnja 1948. godine donijela Uredbu o zavodima za zaštitu i naučno proučavanje spomenika kulture (Narodne novine 50/48), prema kojoj je osnovan Konzervatorski zavod za Dalmaciju u Splitu. Hrvatski državni arhiv u Splitu - arhiv Konzervatorskog odjela u Splitu (dalje: HDAST, AKO-ST), fol. 1967, br. 40_568. Predmet: Prijepis iz: Narodne novine, 50, 173, od 23. lipnja 1948. Br.: 1168/1948. Potpisnici: dr. Ivo Babić - ministar prosvjete; dr. Vladimir Bakarić - predsjednik Vlade NRH.

5 Cvito Fisković je 1945. godine postao ravnatelj Konzervatorskog zavoda za Dalmaciju u Splitu. Još prije Drugog svjetskog rata 1936. godine radio je kao kustos u Arheološkom muzeju te surađivao s Ljubom Karamanom - glavnim konzervatorom za Dalmaciju u Splitu. U Splitu je zaštita spomenika bila institucionalizirana još od sredine 19. stoljeća s bogatim arhivima, fotodokumentacijom i knjižnicom, pa je mladi Fisković dobio izvanrednu poduku i terensko iskustvo. O radu Cvite Fiskovića tih godina usp. SANDRA ŠUSTIĆ, 2016., 25-43.

6 ANTONIJA MLIKOTA, 2013.

7 CVITO FISKOVIĆ, 1946. O utemeljenju časopisa vidi: SANDRA ŠUSTIĆ, 2016., 420-425.

8 Osvrt na zaduženja najbližih suradnika Cvite Fiskovića vidi u: SANDRA ŠUSTIĆ, 2016., 60-69.

9 Evidentiranje pokretnih spomenika na terenu i proces registracije vidi u: SANDRA ŠUSTIĆ, 2016., 103-115. Posebno su važne njegove „kunsttopografije“ Lastova, Visa, Segeta. Bibliografiju radova vidi u: NEDA ANZULOVIĆ, 2006.

10 HDAST, AKO-ST, fol. 1967-527, Regionalni zavod za zaštitu spomenika kulture Split, br. 13/6-67. Predmet: Zapisnik sjednice radne zajednice Zavoda, 8. veljače 1967. Potpisnik: Milan Ivanišević.

11 NEDA ANZULOVIĆ, 2006.; IVO BABIĆ, 1982.; JOŠKO BELAMARIĆ, 1988. a; 1988. b; NEVENKA BEZIĆ-BOŽANIĆ, 1996.; 1997.; DEŠA DIANA, 1996.; DAVOR DOMANČIĆ, 1976.; 1980.; 1997.; ALENA FAZINIĆ, 1997.; MARINKO GJIVOJE, 1980.; SNJEŠKA KNEŽEVIĆ, 2007.; BRANISLAV LUČIN, 1997.; TONKO MAROEVIĆ, 1971.; 1996.; 1997., 2007., SENA SEKULIĆ GVOZDA-
NOVIĆ, 1978.; FRANKO OREB, 1981.; ŽELJKO RAPANIĆ, 2007.; TOMISLAV RAUKAR, 2007.; NENAD VEKARIĆ, 1988.

12 Kao izvor temeljnih podataka o konzervatorskom djelovanju Cvite Fiskovića (1945. - 1977.) korišteni su izvještaji i dokumenti poslovanja Konzervatorskog zavoda za Dalmaciju. Treba napomenuti da se u radu ne iznose podaci o restauriranju oltara, skulptura i reljefa u kamenu, stilskog namještaja, orgulja, tekstila i liturgijskih predmeta ni predmeta umjetničkog obrta, koji su također restaurirani u vrijeme njegova djelovanja. Također, ne analizira se etika i estetika restauriranja u smislu uklanjanja gotičkih, baroknih i klasicističkih preslika s pojedinih umjetnina. $\mathrm{Na}$ potonju će se tematiku fokusirati zaseban članak o tehnikama i metodologiji rada tadašnje splitske radionice.

13 ZORAIDA DEMORI STANIČIĆ, RADOSLAV TOMIĆ, 2014.

14 Dopisni je član JAZU-a bio od 1948., a punopravni od 12. ožujka 1958. godine. Popis članstva i počasnih članstva vidi u SANDRA ŠUSTIĆ, 2016., 454-455.

15 Izvještaji o radu Zavoda od 1946. do 1954. svjedoče o njegovim redovitim molbama i aktivnostima u očuvanju povijesnog slikarstva i skulpture na obali. Valja napomenuti da je suradnju s restauratorima JAZU-a na konkretnim projektima restauriranja počeo već 1947. godine, kad je Zvonimir Wyroubal restaurirao znamenite umjetnine s područja Dalmacije uoči izložbe Dvanaest vjekova južnoslavenske umjetnosti. No najveći broj suradnji ostvario je sa Stanislavom Deklevom 1952. i 1953. godine na području Dubrovnika i Korčule. SANDRA ŠUSTIĆ, 2016., 117-130. 16 Arhiv Konzervatorskog odjela u Splitu (dalje: AKO-ST), fol. 1952, Jugoslavenska akademija znanosti i umjetnosti, Zagreb (dalje JAZU), br. 602/1952. Predmet: Restauratorski rad u sklopu konzervatorskih zavoda, Savjet za prosvjetu, nauku i kulturu NRH, Zagreb. Datum: 28. V. 1952. Potpisnik: akad. Andrija Štampar, v. r. (predsjednik).

17 AKO-ST, fol. 1952, NRH Savjet za prosvjetu, nauku i kulturu - Odbor za kulturu i umjetnost, br. 9393-1952 Predmet: „kao naprijed“. Poslano Konzervatorskom zavodu za Dalmaciju u Splitu (dalje: KZZD-ST). Zagreb, 25. VI. 1952. Potpisnik: E. Aranjoš, referent (zavodski pečat 30. VI. 1952., br. 551).

18 Za troškove osnivanja i opremanja radionice Cvito Fisković je predvidio početni iznos od 500.000 dinara. AKO-ST, fol. 1952, NRH br.: 551/52. Predmet: Restauratorski rad u sklopu konzervatorskih zavoda, Savjetu za prosvjetu, nauku i kulturu NRH, Odbor za kulturu i umjetnost Zagreb. Split, 2. VII. 1952. Potpisnik: CF. 19 AKO-ST, fol. 1952, NRH br. 551/52. Predmet: Restauratorski rad u sklopu konzervatorskih zavoda. Savjetu za prosvjetu, nauku i kulturu NRH, Odbor za kulturu i umjetnost Zagreb. Split, 2. VII. 1952. Potpisnik: CF.

20 AKO-ST, fol. 1952, NRH Savjet za prosvjetu, nauku i kulturu - Odbor za kulturu i umjetnost, br. k 9393-1952, 30. IX. 1952., Zagreb. Predmet: Osnivanje restauratorske radionice u sklopu konzervatorskih zavoda. Poslano KZZD-ST. Potpisnik: pomoćnik ministra J. Lukatela.

U prijedlogu predračuna rashoda KZZD-a za 1953. godinu spominje se stavka za „Uspostavljanje i uzdržavanje restauratorske 
radionice" u predviđenoj vrijednosti od 500.000 dinara. AKO-ST, fol. 1952, br. k 9393-1952. NRH, KZZD-ST, br. 1018/52. Predmet: Predračun za 1953. god. - prijedlog Split, 20. XI. 1952. Poslano Savjetu za prosvjetu, nauku i kulturu NRH, Planskom odjelu, Zagreb. Potpisnik: direktor Cvito Fisković.

21 AKO-ST, fol. 1953, NRH, KZZD-ST, br. 304/53. Predmet: dr. Fisković, predstavnik Instituta za likovne umjetnosti na savjetovanju konzervatora. Split, 13. IV. 1953. Poslano Krsti Hegedušiću, odjelnom tajniku, Zagreb. Potpisnik: dr. Cvito Fisković. O kojim se umjetninama radi vidi u: SANDRA ŠUSTIĆ, 2016., 117-125, 181-190.

22 Škola primijenjenih umjetnosti, tzv. „Mala akademija“, osnovana je 1947. godine u Splitu pod ravnateljstvom Tomislava Kukoča. Dobrošević kaže da je cilj petogodišnjeg programa bilo učenje umjetničkog zanata. Podaci preuzeti iz intervjua s Filipom Dobroševićem iz srpnja 2011.

23 AKO-ST, fol. 1953, NRH, KZZD-ST, br. 669/53. Predmet: Namještenje za preparatora - drugu Filipu Dobroševiću. Split, 10. VII. 1953. Potpisnik: CF.

24 Budući da je Dobrošević bio spriječen, sredstva namijenjena "Održavanju restauratorske radionice“ umanjena su i prebačena za potrebe kancelarijskog materijala, putne troškove, troškove održavanja i osiguranja zgrade i inventara itd. Kao obrazloženje navedeno je da iznos predviđen za održavanje restauratorske radionice neće biti utrošen zbog "tehničkih teškoća“. Radilo se o svoti od 125.000 jugoslavenskih dinara. AKO-ST, fol. 1953, 5011528, NRH, KZZD-ST, br. 878/53, Split, 28. VIII. 1953. Predmet: Virmanisanje kredita - prijedlog za konzervatora: Ante Goić.

25 Naziv preparator preuzet je iz muzejske struke, a korišten je za djelatnike sa srednjoškolskom naobrazbom. TATJANA MUŠNJAK, 1997., 64.

26 HDAST, AKO-ST, fol. 1957, 1-500, NRH, KZZD-ST, br. 39/57. Predmet: Dobrošević Filip, službenik - ispravak rješenja o postavljanju. Poslano: Savjetu za kulturu i nauku NRH, 10. I. 1957. Potpisnik: CF.

27 HDAST, AKO-ST, fol. 1958, 1-300, NRH, KZZD-ST, br. 146/158. 26. II. 1958. Službena potvrda. Potpisnik: CF.

28 Praksu je obavljao u Restauratorskom zavodu JAZU-a pod mentorstvom Ivice Lončarića (1954.), potom srednjovjekovnom manastiru u Kaleniću kod majstora Franje Hermana (1956.), na Saveznom institutu za zaštitu spomenika u Beogradu (1957.), u restauratorskom ateljeu Narodnog muzeja pod mentorstvom Milorada Medića (nakon 1958.), a posjećivao je i brojne radionice u Rimu, Firenci i Veneciji kako bi usvojio tamošnje metode rada. HDAST, AKO-ST, fol. 1967, akta br. 30 od 50 do 100 528, KZZDST, br. 52/1-62, Savjet za kulturu NRH, Zagreb. Predmet: podaci o specijalizaciji - dostava, 20. I. 1962. Potpisnik: CF. Dopunjeno podacima iz osobne korespondencije s Filipom Dobroševićem. 29 Institut je 1953. godine organizirao u suradnji s KZZD-STom prvi kongres jugoslavenskih konzervatora u Splitu, na kojem se raspravljalo o mnogim konzervatorskim pitanjima; također je dao poticaje za šire zahvate i razvitak suradnje. CVITO FISKOVIĆ, 1960. a, 82.
30 U tom smislu važno je upozoriti na dopis Cvite Fiskovića iz veljače 1956. godine koji je uputio Zavodu za zaštitu spomenika Makedonije: „Mi u restauratorskoj radionici moramo dovršiti jedan vrijedan poliptih iz 15. stoljeća, a ne možemo zbog nedostatka damar-laka. (...) Ujedno te molimo da nam posudiš malo venecijanskog terpentina. Mi ti to možemo odmah platiti ili povratiti kad nam stigne, ili kad ti stigneš ovamo da nam ti budeš gost $i$ učitelj naših restauratora, vjerojatno ovoga ljeta. "HDAST, AKOST, fol. 1956, 1-500, NRH, KZZD-ST, br. 88/56. Predmet: Molba za ustupanje Damar-laka, 1. veljače 1956. Poslano Zdravku Blažiću, Zavod za zaštitu spomenika Makedonije, Skoplje. Potpisnik: CF. 31 Među najvažnijim projektima realiziranim u suradnji sa Saveznim institutom u Beogradu nakon 1954. treba spomenuti restauriranje slike talijanske škole Bogorodica s Djetetom autora Quarizija da Murana, koja je stajala u otvoru pala portante na oltaru Garagnin-Fanfogna u katedrali sv. Lovre u Trogiru (1957.) te zahvat na oltarnoj slici Natalina da Murana Sv. razgovor iz 16. stoljeća, smještene u crkvi Gospe od Šunja na Lopudu (od 1962. do 1968. godine). SANDRA ŠUSTIĆ, 2016.

32 Disertaciju je obranio pred povjerenstvom: dr. Artur Schneider, dr. Viktor Hoffiller, dr. Ferdo Šišić i dr. Pavao Vuk. Datum je naveden na internetskoj stranici Digitalnog akademskog repozitorija (DAR). Međutim, u arhivskim spisima čuvanim u arhivu AKO-ST-a navodi se datum 30. lipnja 1937. kao datum obrane doktorata. AKO-ST, fasc. 1945-1977/1948/1948 br. 1-380, Stručni karton, 15. 3. 1948.

33 HDAST, Oblasni narodnooslobodilački odbor Dalmacije (dalje: ONOOD) - izvrsni odbor - fol. 1, spisi od I do XI - 1943-4547-48-49, Oblasni NOO Dalmacije, Prosvjetni odio, br. 421/44, Split 4. 11 (?). 1944. Predmet: Izvještaj o prosvjetnom radu. Poslano: Zemaljskom antifašističkom vijeću Narodnog oslobođenja Jugoslavije - Odjelu narodne prosvjete. Pročelnik: Cvito Fisković. 34 HDAST, ONOOD - izvrsni odbor - fol. 1, spisi od I do XI 1943-45-47-48-49, ONOOD - Prosvjetni odio, br. 2650/45. Split, 23. VI. 1945. Narodna vlada Hrvatske - Ministarstvo prosvjete - Kulturno-umjetnički odsjek, Zagreb. Potpisnici: pročelnik, dr. Cvito Fisković predsjednik, potpisnik nečitak.

$35 \mathrm{Na}$ tu se situaciju osvrnuo Ivo Babić u predgovoru napisanom za Eseje 1982.: „Govoriti da je dalmatinska kulturna baština djelo domaćih umjetnika slavenskog, hrvatskog porijekla zvuči poput pleonazma ali u vrijeme kad Fisković započima svoj znanstveni rad iredentistički nastrojena talijanska historija umjetnosti negira njenu dominantnu autohtonu komponentu." IVO BABIĆ, 1982., 9. 36 HDAST, AKO-ST, fol. 1955, 401-1270, NRH; KZZD-ST, br. 1111/55. Predmet: restauriranje umjetnina u Dalmaciji, Odjel za likovne umjetnosti Jugoslavenske akademije znanosti i umjetnosti, Zagreb. 5. XII. 1955. Potpisnik: CF.

37 HDAST, AKO-ST, fol. 1955, 401-1270, KZZD-ST, br. 1094/55. Predmet: Upitnik ICOM-a, 26. XII. 1955. Poslano Saveznom institutu za zaštitu spomenika kulture, Beograd. Potpisnik: CF. 38 HDAST, AKO-ST, fol. 1961, br. VI od 50 do 100, KZZD-ST, br. 60/4-1961. 11. srpnja 1961. Župski ured Milna, Predmet: Popravak slika. CF.

39 ZORAIDA DEMORI STANIČIĆ, 2017., 253, 258-261. 
40 ZORAIDA DEMORI STANIČIĆ, 1986. - 1987.

41 HDAST, AKO-ST, fol. 1975, 16 do 22 340, RZZSK-ST, br. 17/14-75 Split, 29. kolovoza 1975., Potpisnik: CF. Zanimljivo je spomenuti da stručnjaci Nacionalne galerije u Londonu 1972. počinju publicirati časopis National Gallery Technical Bulletin koji je pokazao kontinuirani porast suradnje kustosa, znanstvenika i restauratora u studijama na umjetninama.

42 HDAST, AKO-ST, fol. 1975, 16 do 22 340, Regionalni zavod za zaštitu spomenika kulture u Splitu (dalje: RZZSK-ST), br. 17/1475. Poslano Fondu za financiranje znanstveno istraživačke djelatnosti skupštine općine Split, 29. kolovoza 1975. Potpisnik: CF. 43 ZLATKO GALL, 1987., 11.

44 Istraživanje je proveo i u knjižnicama sveučilišta u Bariju, potom u Parizu (Institut des études Slaves) te na Institutu za povijest umjetnosti Fondazione Cini u Veneciji. U Anconi je popisao sve spomenike koji su u vezi s djelatnošću dalmatinskih majstora i kulturnim razvitkom, osobito Dubrovčana. HDAST, AKO-ST, fol. 1967, akta br. 30 od 50 do 100 528, KZZSD-ST, br. 52/1-62, Savjet za kulturu NRH, Zagreb. Predmet: podaci o specijalizaciji - dostava, 20. I. 1962. Potpisnik: CF. Nakon tih pothvata objavio je dvije studije u časopisu Mogućnosti: članak „Hrvatski umjetnici u Mlecima“, objavljen 1956. godine, te „Naše umjetničke veze s južnom Italijom“, objavljen 1961. godine.

45 HDAST, AKO-ST, fol. 1961, akta, broj VII od 100 do 150, KZZS-ST, br. 133/1-61 10. V. 1961. Savjet za naučni rad, NRH Zagreb. Predmet: Perspektivni rad - program naučno-istraživačkog rada. Potpisnik: CF.

46 Izložba očišćenih slika održana 1947. u Nacionalnoj galeriji u Londonu potaknula je val međunarodnih rasprava. Naime, izvjestan broj kritičara osudio je provedeno čišćenje kao pretjerano (baš kako se to dogodilo sto godina prije, dok je galerijom upravljao sir Charles Lock Eastlake). Formirale su se dvije struje: oni koji su držali da su čišćenjem uklonjene izvorne lazure i tonirani lakovi (talijanski restauratori na čelu s Cesareom Brandijem) te oni koju su u takvom zahvatu vidjeli mogućnost prikazivanja umjetnikove intencije. HAN, 1952.

47 HDAST, AKO-ST, fol. 1958, 1-300, NRH, KZZD, br. 191/1-58. Redakciji Vjesnika - drugu Mladenu Stary. Zagreb, 19. III. 1958. Potpisnik: CF.

48 Projekt koji je među prvima demonstrirao dobrobit interdisciplinarne suradnje povjesničara umjetnosti, restauratora $\mathrm{i}$ laboratorijskih stručnjaka svakako je obnova Gentskog oltara, remek-djela braće Van Eyck, u Restauratorskom ateljeu Centralnog laboratorija belgijskih muzeja u Bruxellesu 1950. godine. U tom smislu ICOM, čiji je Fisković bio član, preuzeo je ulogu obavještavanja i koordinaciju informacija na tom području. ANIKA SKOVRAN, 1956., 167.

49 CVITO FISKOVIĆ, 1968., 101.

50 HDAST, AKO-ST, fol. 1965, god. 31 do \_\_ 558 KZZD-ST, br. 121/3-1966. Split, 23. III. 1966. Ispitnoj komisiji za polaganje stručnih ispita Zagreb. Predmet: Katić Špiro polaganje stručnog ispita - dostava ispitne radnje. Potpisnik: Edgar Gross.

51 Zoraida Demori Staničić u skriptama Povijest restauracije za studente Umjetničke akademije sveučilišta u Splitu iznosi mišljenje o radu radionice: „Takav je rad rezultat i odraz jedne dobro postavljene suradnje kakve nije bilo u zagrebačkoj radionici koja je bila više hermetički zatvorena u samu sebe, pa iz nje nije izlazilo toliko doprinosa povijesti umjetnosti." Razumljivo, u Restauratorskom zavodu JAZU-a u Zagrebu također su se formirala Povjerenstva za pregled umjetnina. Primjer takvog povjerenstva formiran je u slučaju restauriranja slike Krist pada pod križem iz Strossmayerove galerije u Zagrebu, izvedenom od 1953. do 1956. godine. Sačuvana dokumentacija svjedoči o složenoj proceduri u donošenju odluka o restauratorskim radovima koja je uz restauratora Zvonimira Wyroubala uključivala stručnjake s područja likovnih umjetnosti (Jerolim Miše, Ljubo Babić), no i opunomoćenika vlasnika (Ivy Kugli). VIŠNJA BRALIĆ, PAVAO LEROTIĆ, 2010., 167.

52 Među prvim slučajevima restauriranja koje je nadziralo četveročlano povjerenstvo bila je slika Bogorodica s dva sveca iz 16. stoljeća (inv. br. 18.1956) u vlasništvu obitelji Radić. Kao članovi komisije potpisani su: Fisković, Cicarelli, Dobrošević i Domančić. Restauriranje slike Bogorodica s Djetetom iz 15. stoljeća (inv. br. 46 38) u vlasništvu župne crkve u Trogiru, preuzete 4. studenog 1957. godine. AKO-ST, Radionički arhiv, fol. 1955-56-57.

53 Podaci preuzeti iz dokumentacijskog kartona o raspelu (inv. br. 1/69) AKO-ST, Radionički arhiv, fol. 1969.

54 Cvito Fisković je spomenutom dopisu priložio i zapisnik s prvog sastanka o restauriranju raspela.

55 Podaci su preuzeti iz dokumentacije, tj. troškovnika o restauraciji slike (registr. 339) AKO-ST, Radionički arhiv, fol. 1975. 56 HDAST, AKO-ST, fol. 1968. VI. 101 do dalje 1968 532, br. 112/68 19. IX. 1968. Nepotpisano.

57 CVITO FISKOVIĆ, 1968., 100.

58 Osim Splita, važne romaničke slike locirane su u Zadru, Hvaru i Trogiru. To su sljedeće slike: velika slika Bogorodice sa sinom i donatorom iz Zadra, Bogorodica iz zadarske stolne crkve, slika Bogorodice sa sinom pizanske škole s Hektorovićeva oltara u hvarskoj stolnoj crkvi iz druge polovice 13. stoljeća te romanička ikona iz crkve benediktinki sv. Nikole u Trogiru, „skrivena“ pod srebrnim pokrovom u pali portatile. CVITO FISKOVIĆ, 1960. a, 86.; CVITO FISKOVIĆ, 1976.

59 Lovorka Čoralić i Ivana Prijatelj Pavičić navode u članku iz 2001. godine da je zahvat na slici izveden 1960. godine pod vodstvom Filipa Dobroševića. LOVORKA ČORALIĆ, IVANA PRIJATELJ PAVIČIĆ, 2011., 356.

No prema dopisu Cvite Fiskovića poslanom Župnom uredu u Splitu od 1. srpnja 1957., sliku su restaurirali tri godine prije zagrebački restauratori JAZU-a: „Čast mi je uputiti Vam naš pred$\log$ za natpis trečentističke slike Madone koja je restaurirana u Restauratorskom laboratoriju Jugoslavenske akademije znanosti i umjetnosti u Zagrebu (...) RESTAURATUM ANNO NATIVITATIS DOMINI MCMLVII.“ HDAST, AKO-ST, fol. 1957, 501-1000, KZZDST, NRH, br. 706/57. Predmet: Natpis na slici Gospe od zvonika Župskom uredu u Splitu, 1. 7. 1957. Potpisnik: CF.

60 Godine 1933. Ljubo Karaman navodi da umjetnina pripada baroknom razdoblju. LJUBO KARAMAN, 1933., 152. Dvadesetak 
godina poslije Kruno Prijatelj drži da je riječ o kasnogotičkom poliptihu. KRUNO PRIJATELJ, 1951., 11.

61 CVITO FISKOVIĆ, 1960., 93.

62 IGOR FISKOVIĆ, 1968., 102-108.

63 Znanstvene studije o tim umjetninama Cvito Fisković je objavljivao redom pronalaženja slika: CVITO FISKOVIĆ,1960.; 1966.; 1970.; 1971.; 1994.

64 lako se pojam „splitska slikarska škola“ upotrebljava i danas, akademik Igor Fisković drži da je mnogo prikladniji pojam „splitska slikarska radionica“. IGOR FISKOVIĆ, 2012., 108.

65 Ljubo Karaman je Bogorodicu s Djetetom iz crkve sv. Stjepana na Sustipanu datirao u barokno razdoblje. LJUBO KARAMAN, 1933. U kasnogotičko razdoblje navedenu sliku je svrstao Kruno Prijatelj. KRUNO PRIJATEL), 1951. Raspelo iz sv. Klare Ljubo Karaman je povezao sa slikarstvom hrvatskih majstora, no nije ga povezao s navedenim umjetninama. LJUBO KARAMAN, 1954. 66 Među prvim stručnjacima koji su prihvatili tu tezu su: VOJISLAV J. ĐURIĆ, 1961. KRUNO PRIJATELJ, 1961. Nove spoznaje o romaničkom slikarstvu donosi akademik Igor Fisković, pišući o ciklusu fresaka na Šipanu i Koločepu, gdje ikonografske i likovne specifičnosti upućuju na benediktinske narudžbe. Sve podupire tezu o srodnostima toga slikarstva s onim iz pokrajina južne Italije, što se sa sigurnošću vezuje uz rad „grčkih majstora“. IGOR FISKOVIĆ, 2009., 17.

67 HDAST, AKO-ST, fol. 1972, 13-15 311, RZZSK-ST, br. 14/1272, Split, 28. travnja 1972. Poslano Republičkom fondu za unapređenje kulturnih djelatnosti, Zagreb. Potpisnik: CF.

68 Ukupnu bibliografiju radova napisala je Zoraida Demori Staničić u katalogu prve monografske izložbe toga majstora, održane u Splitu 1986. godine. ZORAIDA DEMORI STANIČIĆ, 1986. - 1987. 69 CVITO FISKOVIĆ, 1956., 145.

70 CVITO FISKOVIĆ, 1961., 114-132.

71 U članku o splitskom raspelu iz 1962. godine Cvito Fisković navodi dotadašnja istraživanja drugih povjesničara umjetnosti o toj temi. Ljubo Karaman je 1932. godine primijetio da se zbog „prejake restauracije otimlje sigurnom sudu u njegovom slogu i o dobi njegova postanka“, iako mu je istaknuo „trečentistički

\section{Izvori}

Arhiv Oblasnog narodnooslobodilačkog odbora Dalmacije pohranjen u Hrvatskom državnom arhivu u Splitu (HDAST-ONOOD). Arhiv Konzervatorskog zavoda za Dalmaciju - spisi od 1945. do 1953. godine pohranjeni u Konzervatorskom odjelu u Splitu (AKO-ST).

Arhiv Konzervatorskog zavoda za Dalmaciju - spisi 1945. do 1977. godine pohranjeni u Hrvatskom državnom arhivu u Splitu (HDAST-AKO-ST).

\section{Literatura}

NEDA ANZULOVIĆ, Bibliografija Cvita Fiskovića, Institut za povijest umjetnosti, Zagreb, 2006.

IVO BABIĆ, Cvito Fisković: Eseji, Split, 1982. karakter", dok ga je Kruno Prijatelj 1951. ubrojio u djela domaće slikarske škole XV. stoljeća. CVITO FISKOVIĆ, 1962., 48.

72 HDAST, AKO-ST, fol. 1963, 2 od 28 do 601963 546, NRH KZZD-ST, br. 28/90-1963, poslano Grgi Gamulinu. Predmet: Suradnja u Peristilu i konzervacija slika. Zagreb, 1. XI. 1963. Potpisnik: CF.

73 KSENIJA CICARELLI, 1960.

74 IGOR FISKOVIĆ, 1969., 705.

75 Uz navedene stručnjake, Cvito Fisković se konzultirao s dr. don Ivanom Ostojićem i prof. Hrvojem Morovićem, koji su jedini u Splitu znali tumačiti glagoljicu, ali nažalost nisu uspjeli protumačiti sva slova. HDAST, AKO-ST, fol. 1973, 16 do 22329 RZZSK-ST, br. 19/23-73, Split, 23. ožujka 1973. Poslano: gospodinu prof. Vjekoslavu Štefaniću, Zagreb, CF.

76 CVITO FISKOVIĆ, BENEDIKTA ZELIĆ-BUČAN, 1975., 70.

77 Usp.: CVITO FISKOVIĆ, 1968., 98-102.; IGOR FISKOVIĆ, 1968.,102-108.

78 KSENIJA CICARELLI, DAVOR DOMANČIĆ, 1968.

79 IGOR FISKOVIĆ, 1969., 703-706.

80 HDAST, AKO-ST, fol. 1968, II 17 do 201968 534, RZZSK-ST, br. 17/10-68, Zavod za zaštitu spomenika kulture Split, 30. X. 1968. Potpisnik: Filip Dobrošević.

81 Davor Domančić u predgovoru kataloga izložbe Djela Blaža Jurjeva Trogiranina izvještava: „Samo su tri Blaževa djela popravljena u Restauratorskoj radionici Jugoslavenske akademije znanosti i umjetnosti u Zagrebu: Korčulanski poliptih iz Opatske riznice 1952. god., poliptih iz Sv. Jakova u Trogiru 1961. god. na kojem je otkriven Blažev potpis, te, konačno, iste godine, Gospa s djetetom iz zadarske crkve Gospe od zdravlja, slika na kojoj je na istaknutom mjestu Blaž ostavio svoj potpis i godinu slikanja. Pri ponovnom osvježenju poliptiha Sv. Jakova u Restauratorskoj radionici u Splitu 1984. god. otkriven je pod likom sv. Jakova, a niže od Blaževa potpisa, zapis imena Vlatka Budića (Budinića), vjerojatno Blaževa suradnika koji mu je u radionici mogao biti od pomoći.“ DEMORI STANIČIĆ, 1986. - 1987., 88.; DAVOR DOMANČIĆ, 1987.; MARGARITA ŠIMAT, 1989.; BISERKA RAUTER PLANČIĆ, 2001.

Arhiv restauratorske radionice Konzervatorskog zavoda za zaštitu spomenika u Splitu pohranjen u Konzervatorskom odjelu u Splitu (AKO-ST-ARR).

Fototeka Konzervatorskog odjela u Splitu.

JOSIP BELAMARIĆ, O krađama umjetnina, Povratak Palme Mlađeg, Katalog izložbe Regionalnog zavoda za zaštitu spomenika kul- 
ture, (ur.) Davor Domančić, Split, Regionalni zavod za zaštitu spomenika kulture, 1988., 11-31.

JOSIP BELAMARIĆ, Rad Cvita Fiskovića na izučavanju i zaštiti naše kulturno-povijesne baštine, Anali Zavoda za povijesne znanosti Jugoslavenske akademije znanosti i umjetnosti u Dubrovniku, 26 (1988. a), 241-245.

JOSIP BELAMARIĆ, U povodu osamdeset godina života Cvita Fiskovića, Anali Zavoda za povijesne znanosti HAZU u Dubrovniku, 26 (1988. b), 237-240.

NEVENKA BEZIĆ BOŽANIĆ, Sugovornik naraštaja, Mogućnosti XLIV, 1-3 (1997.), 153-154.

NEVENKA BEZIĆ BOŽANIĆ, U spomen Cvitu Fiskoviću, Čakavska rič, 1/2 (1996.), 1-6.

VIŠNJA BRALIĆ, PAVAO LEROTIĆ, „Krist pada pod križem” iz Strossmayerove galerije u Zagrebu: crtica iz povijesti restauriranja baroknog slikarstva u Hrvatskoj, Portal, godišnjak Hrvatskog restauratorskog zavoda, 1 (2010.), 161-174.

BRANISLAV LUČIN, Cvito Fisković (1908 - 1996) In memoriam, Colloquia Maruliana, 4 (1997.), 281-282.

KSENIJA CICARELLI, Prilog trogirskom slikarstvu XV. stoljeća, Prilozi povijesti umjetnosti u Dalmaciji, 12 (1960.), 155-159. KSENIJA CICARELLI, DAVOR DOMANČIĆ, Exposition de la peinture romane sur bois en Dalmatie des XIle et XIIle siecles, a I'occasion du colloque international d'historie de l'art, Split, 1968.

PAUL COREMANS, Očuvanje kulturnih dobara u Jugoslaviji, Zbornik zaštite spomenika kulture, 10 (1960.), 5-9. LOVORKA ČORALIĆ, IVANA PRIJATELJ PAVIČIĆ, Prilog poznavanju splitske crkvice Gospe od Zvonika, Prilozi povijesti umjetnosti u Dalmaciji, 39 (2005.), 355.

ZORAIDA DEMORI STANIČIĆ, Katalog izložbe Blaž Jurjev Trogiranin, Split - Zagreb, 1986. - 1987.

ZORAIDA DEMORI STANIČIĆ, Javni kultovi ikona u Dalmaciji, Split - Zagreb, 2017.

ZORAIDA DEMORI STANIČIĆ, RADOSLAV TOMIĆ, Šezdeset godina restauratorske radionice u Splitu - katalog izložbe restauriranih umjetnina, Hrvatski restauratorski zavod, 2014.

DIANA DEŠA, Cvito Fisković (Orebić, 1908. - Split, 1996.), Hrvatska obzorja - Časopis Matice hrvatske, 4/3 (1996.),173-175.

DAVOR DOMANČIĆ, Nagrada AVNOJ-a za 1977. godinu akademiku Cvitu Fiskoviću, Godišnjak zaštite spomenika kulture Hrvatske, 2 (1976.), 5-6.

DAVOR DOMANČIĆ, Predgovor (uvodni tekst o Cviti Fiskoviću), Fiskovićev zbornik I, Zbornik radova posvećen sedamdesetogodišnjici života Cvite Fiskovića - Prilozi Povijesti umjetnosti u Dalmaciji, 21 (1980.), 5-8.

DAVOR DOMANČıĆ (ur.) et. al., Blaž Jurjev Trogiranin, katalog izložbe, (Muzej hrvatskih arheoloških spomenika, Split, listopad, studeni, prosinac 1986., Muzejski prostor, Zagreb, siječanj, veljača, ožujak, 1987.), prevodilac William Yuill; fotografije Živko Bačić. DAVOR DOMANČIĆ, In memoriam Cvito Fisković (1908 - 1996), Godišnjak zaštite spomenika kulture Hrvatske, 22 (1997.), 193-195. VOJISLAV J. ĐURIĆ, Ikone iz Jugoslavije - katalog izložbe, Beograd, 1961., 41-44.
ALENA FAZINIĆ, In memoriam dr. Cvito Fisković (1909 - 1996), Godišnjak grada Korčule, 2 (1997.), 209-212.

CVITO FISKOVIĆ, Dalmatinski spomenici i okupator, Konzervatorski zavod za Dalmaciju u Splitu, Split, 1946.

CVITO FISKOVIĆ, Dubrovačka skulptura, Dubrovnik - časopis za književnost, nauku i umjetnost, II/1 (1956), 58-68.

CVITO FISKOVIĆ, Neobjavljena romanička Madona u Splitu, Prilozi povijesti umjetnosti u Dalmaciji, 12 (1960.), 85-100.

CVITO FISKOVIĆ, Radovi Saveznog instituta u Dalmaciji, Zbornik zaštite spomenika kulture, 5/XI (1960. a), 81-90.

CVITO FISKOVIĆ, Neobjavljeno djelo Blaža Jurjeva u Stonu, Prilozi povijesti umjetnosti u Dalmaciji, 13 (1961.), 114-132.

CVITO FISKOVIĆ, Neobjavljeno djelo Blaža Jurjeva u Splitu. Riassunto, Peristil, 5 (1962.), 45-51.

CVITO FISKOVIĆ, Neobjavljena romanička Gospa iz Splita, $P e$ ristil, 8-9 (1966.), 13-24.

CVITO FISKOVIĆ, Riječ pri otvaranju izložbe restauriranih umjetnina u Splitu, Mogućnosti, 15 (1968.), 98-102.

CVITO FISKOVIĆ, Romaničko raspelo iz crkve sv. Križa u Splitu, Peristil, 12-13 (1970.), 5-14.

CVITO FISKOVIĆ, Romaničko raspelo u splitskom Varošu, Slobodna Dalmacija, XXIX/8135 (5. svibnja 1971.), 4.

CVITO FISKOVIĆ, BENEDIKTA ZELIĆ- BUČAN, O poliptihu Blaža Jurjeva u Trogiru, Prilozi povijesti umjetnosti u Dalmaciji, 20/2, (1975.), Split, 67-72.

CVITO FISKOVIĆ, Prinova romaničkom slikarstvu 13. stoljeća u Dalmaciji - Trogirska ikona, Slobodna Dalmacija, XXXIV/9572 (10. siječnja 1976.), 7.

CVITO FISKOVIĆ, Splitske slikarske radionice romaničkoga sloga, Kačić - Zbornik franjevačke provincije presvetoga otkupljenja, XXVI (1994.) 373-378.

IGOR FISKOVIĆ, Prva izložba starih umjetnina popravljenih u Splitu, Mogućnosti, XV/1 (1968.), 102-108.

IGOR FISKOVIĆ, Druga izložba starih umjetnina popravljenih u Splitu, Mogućnosti, XVII/6 (1969.), 703-706.

IGOR FISKOVIĆ, Slikano raspelo sv. Franje iz 13. stoljeća u Splitu, Radovi Instituta za povijest umjetnosti, 36 (2012.), 97-112.

ZLATKO GALL, Dalmacija nosi usud oko vrata - intervju s Cvitom Fiskovićem, Slobodna Dalmacija, 13133 (18. lipnja 1987.), 11. MARINKO GJIVOJE, Bibliografija radova Cvita Fiskovića, Prilozi povijesti umjetnosti u Dalmaciji (Fiskovićev zbornik I), 21 (1980.), 5-40. VERNA HAN, Problem čišćenja slika - predmet internacionalne diskusije, Zbornik zaštite spomenika kulture, 2 (1952.), 51-57. LJUBO KARAMAN, Umjetnost u Dalmaciji XV i XVI. vijek, Zagreb, 1933., 152.

LJUBO KARAMAN, Osvrt na neke novije publikacije i tvrdnje iz područja umjetnosti Dalmacije, Peristil, I (1954.), 41-44.

SNJEŠKA KNEŽEVIĆ, Poetičnost fakta (O recepciji djela C. Fiskovića), Mogućnosti, 1-3 (2007.), 25-30.

TONKO MAROEVIĆ, Listovi palme, listovi papira - Stvarnost stvarnosti starijeg hrvatskog pjesništva, Teka, 1 (1971.), 158-165. TONKO MAROEVIĆ, In memoriam Cvito Fisković (1908-1996), Radovi Instituta za povijest umjetnosti, 20 (1996.), 189-194 
TONKO MAROEVIĆ, Duh doma, Mogućnosti, XLIV/1/3 (1997.), 154-160.

TONKO MAROEVIĆ, Primarno, spontano, temperamentno Cvito Fisković kao likovni kritičar, Mogućnosti, 1/3 (2007.) 1-14. ANTONIJA MLIKOTA, Obnova i izgradnja povijesne jezgre Zadra nakon razaranja u Drugom svjetskom ratu, doktorska disertacija, Filozofski fakultet, Zagreb, 2013.

TATJANA MUŠNJAK, Školovanje stručnjaka na području konzerviranja i restauriranja pisane baštine, Arhivski vjesnik, 40 (1997.), 63-69.

KRUNO PRIJATEL), Slike domaće škole XV. stoljeća u Splitu (izdanje Galerije umjetnina u Splitu br. 5) 1951., 11.

KRUNO PRIJATELJ, Slikano raspelo iz samostana Sv. Klare u Splitu, Peristil, 4 (1961.), 9-15.

ŽELJKO RAPANIĆ, Cvito Fisković - arheolog, Mogućnosti, 1-3 (2007.), 19-24

TOMISLAV RAUKAR, Likovnost i društvo u djelu Cvita Fiskovića, Mogućnosti, 1-3 (2007.) 15-18.

BISERKA RAUTER PLANČIĆ (ur.), Blago trogirskih riznica: umjetničko i kulturno nasljeđe od 1000. do 1600. g., (Galerija Klovićevi dvori, 27. prosinca 2001. - 3. ožujka 2002.), fotografije Živko Bačić et al., Zagreb, Galerija Klovićevi dvori, 2001.

SENA SEKULIĆ GVOZDANOVIĆ, Nagrada AVNOJ-a 1977. Cviti

Fiskoviću, Čovjek i prostor, XXV/298 (1978.), 22.
ANIKA SKOVRAN, Stav Centralne laboratorije belgijskih muzeja prema glavnim problemima restauracije slika, Zbornik zaštite spomenika kulture, IV-V (1956.), 167-189.

SAGITA MIRJAM SUNARA, Prilog poznavanju djelovanja Ferde Goglie, restauratora Arheološkog, tj. Arheološko-historičkog odjela Narodnog muzeja u Zagrebu, Godišnjak zaštite spomenika kulture Hrvatske, 35 (2011.), 41-50.

SAGITA MIRJAM SUNARA, Život i djelo Zvonimira Wyroubala, doktorska disertacija, Zagreb, 2017.

MARGARITA ŠIMAT (ur.), Biagio di Giorgio da Trau: 1375c.-1450.: catalogo della mostra / prevoditeljica Nicoletta Babić et al., MCC Zagreb, 1989.

IVO ŠIŠEVIĆ, Doprinos Cvite Fiskovića povijesnoj kulturi našeg pomorstva, Dubrounik - časopis za književnost, nauku i umjetnost, 21/6 (1978.), 97-100.

SANDRA ŠUSTIĆ, Djelovanje Cvite Fiskovića na zaštiti i restauraciji povijesnoga slikarstva i skulpture na hrvatskoj obali, doktorska disertacija, Filozofski fakultet, Zagreb, 2016.

NENAD VEKARIĆ, Bibliografija radova Cvita Fiskovića 1979-1988, Anali Zavoda za povijesne znanosti Jugoslavenske akademije znanosti i umjetnosti u Dubrovniku, 26 (1988.), 247-254.

\section{Summary}

Sandra Šustić

CVITO FISKOVIĆ AND THE MAIN FEATURES OF ART CONSERVATION AT THE CONSERVATION DEPARTMENT FOR DALMATIA

At the beginning of the second half of the $20^{\text {th }}$ century, an unprecedented number of historical paintings and sculptures from the Croatian coast lay neglected and unprotected. Furthermore, because of the destruction during World War II, many famous artworks from the coast had additional damage, were stolen or lost. Such an alarming state prompted the organization of a protection service which would focus primarily on works of art from Dalmatia. However, the existing institutions dealing with heritage protection could not be put in charge of rescuing such a large number of Dalmatian monuments. While the Conservation Institute, founded by the Yugoslav Academy of Sciences and Arts in Zagreb (JAZU), worked primarily on the conservation of damaged items from galleries and museums of the Academy, the Federal Institute for the Protection of Cultural Monuments in Belgrade chose artworks based on the criterion of the so-called 'federal' significance of endangered items. Therefore, the arrival of a new director at the Conservation Department for Dalmatia in 1945 - art historian and conservator, Cvito Fisković (Orebić, 24 December 1908 - Split, 13 July 1996) - made it possible to save cultural heritage from Dalmatia. In 1954, when the first conservation workshop in Split was founded, the only workshop of this type in Dalmatia, work on the systematic conservation of historical paintings and sculptures could begin.

Prior to his active involvement, the work of what he often called "local masters" on the Adriatic was not well known, so their significance in the cultural affirmation of Dalmatian art on the Adriatic was not noticed. The basic success in solving this specific type of problem in art history from 1945 onwards consisted of dealing with artistic products by Dalmatian builders, sculptors, painters, carvers and goldsmiths on the Adriatic coast. The work on implementing this project affected the work of the Conservation Department. Therefore, thorough preliminary research of artwork was carried out during the protection, registration and conservation of cultural and artistic heritage. Through this approach, and with close co-operation with his colleagues, Cvito Fisković furthered the knowledge on masters from Dalmatia, and enabled them to be identified, conserved and restored, and finally published. Furthermore, his role in the formation of interdisciplinary studies in art conservation, where the knowledge and expertise of art historians and restorers complement each other, is especially important. In fact, in respecting the role of restorers who understood the materiality of art, a lot of information that made a significant 
contribution to art history was collected. A perfect example of affirmation of artists from Dalmatia was the discovery of the Romanesque school in Split, and the enrichment of the oeuvre of Blaž, son of Juraj of Trogir. Preliminary studies that resulted from it yielded numerous research papers that confirmed and scientifically proved the development of Dalmatian artists from the $9^{\text {th }}$ to the $20^{\text {th }}$ century. His idea of involving experts with varying expertise strengthened the projects of the Split Conservation Workshop and enabled authoritative conclusions in the field of art history. The research results - which are part of broader research on the protection, conservation and restoration of movable monuments under the leadership of Cvito Fisković - have undoubtedly proven that he played a very important role in the creation and promotion of the protection of movable monuments in Croatia, by modernising the work of his predecessors and expanding the study of the art that was being conserved and restored.

KEYwords: Cvito Fisković, Conservation Department for Dalmatia, Split Conservation Workshop, art conservation and restoration, movable monuments, "local" masters, interdisciplinary cooperation 